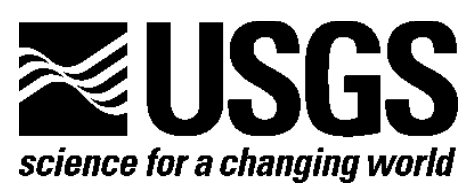

\title{
Tools and Methods for Evaluating and Refining Alternative Futures for Coastal Ecosystem Management-the Puget Sound Ecosystem Portfolio Model
}

By Kristin B. Byrd, Jason R. Kreitler, and William B. Labiosa

Open-File Report 2011-1279

U.S. Department of the Interior

U.S. Geological Survey 


\section{U.S. Department of the Interior \\ KEN SALAZAR, Secretary}

U.S. Geological Survey
Marcia K. McNutt, Director

U.S. Geological Survey, Reston, Virginia: 2011

For product and ordering information:

World Wide Web: http://www.usgs.gov/pubprod

Telephone: 1-888-ASK-USGS

For more information on the USGS—the Federal source for science about the Earth, its natural and living resources, natural hazards, and the environment:

World Wide Web: http://www.usgs.gov

Telephone: 1-888-ASK-USGS

Suggested citation:

Byrd, K.B, Kreitler, J.R, and Labiosa, W.B, 2011, Tools and methods for evaluating and refining alternative futures for coastal ecosystem management-the Puget Sound Ecosystem Portfolio Model: U.S. Geological Survey Open-File Report 2011-1279, 47 p., available at http://pubs.usgs.gov/of/2011/1279/.

Any use of trade, product, or firm names is for descriptive purposes only and does not imply endorsement by the U.S. Government.

Although this report is in the public domain, permission must be secured from the individual copyright owners to reproduce any copyrighted material contained within this report. 


\section{Contents}

Acronyms Used in This Report.........................................................................................

Acknowledgments ........................................................................................................ vii

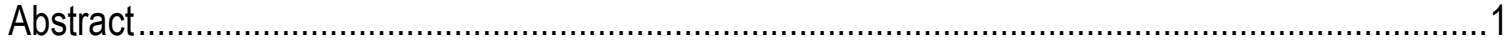

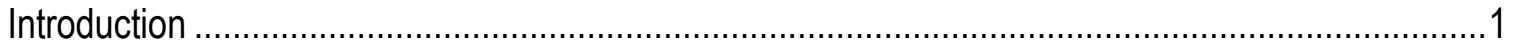

Ecosystem Services and Valued Ecosystem Components (VECs) ...........................................2

Puget Sound Growth Scenarios Through 2060 ………………....................................2

Overview of the Puget Sound Ecosystem Portfolio Model ..........................................................

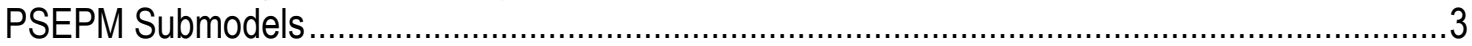

PSEPM Web-Enabled Data Visualization .........................................................................

PSEPM Submodels for Evaluating Alternative Futures .............................................................

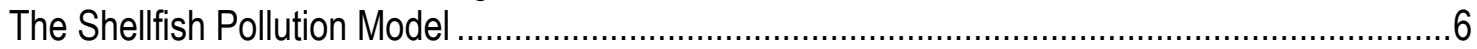

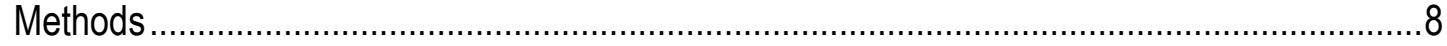

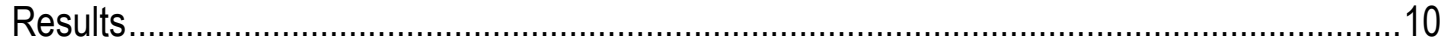

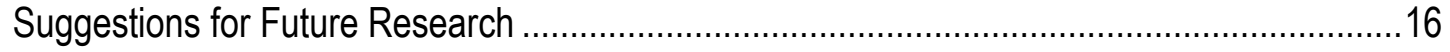

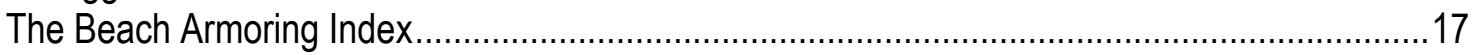

Components of Index Development..............................................................................

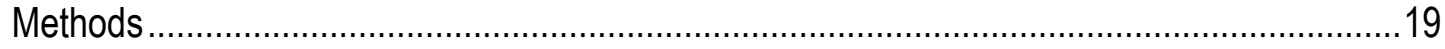

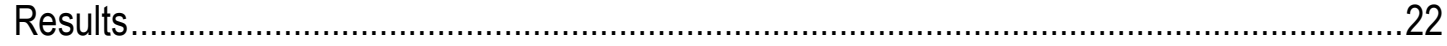

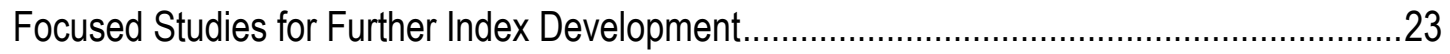

Suggestions for Future Research ..............................................................................32

The Recreational Visitation Model...................................................................................

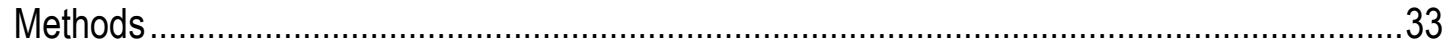

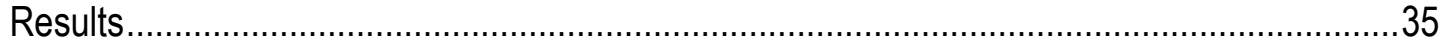

Suggestions for Future Research ..............................................................................37

Model Synthesis to Evaluate Potential Impacts to Valued Ecosystem Components and

Ecosystem Services .................................................................................................

Forage-fish Spawning Habitat-An Intersection of Beach Armoring Index Scores at Forage-

fish Spawning Beaches ...................................................................................... 38

Recreational Shellfish Beaches-Recreational Shellfish Harvests and Surrounding Water

Quality

Recreational Beach Quality -An Intersection of Beach Armoring Index Scores and

Recreational Visits at State Beaches, Classified by Access Type .........................................41

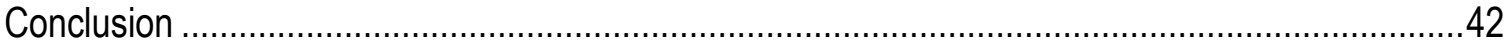

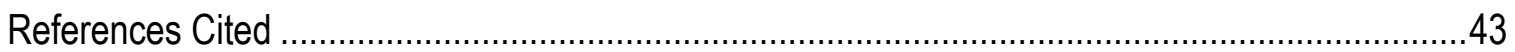




\section{Figures}

1. The Land-Water-Human Connection-Changes to metrics of nearshore condition under alternative growth scenarios.

2. Three-map viewer in the Puget Sound Ecosystem Portfolio Model Web-based (WebGIS) application. This Web page

3. Diagram of shellfish pollution scenario analysis in the Puget Sound Ecosystem Portfolio Model.

4. Predicted fecal coliform bacteria counts used in the Shellfish Pollution Model component of the Puget Sound Ecosystem Portfolio Model.

5. Fitted versus actual fecal coliform bacteria counts used in the Shellfish Pollution Model component of the Puget Sound Ecosystem Portfolio Model.

6. Average predicted fecal coliform bacteria count by subbasin and decade for each

ENVISION scenario used in the Shellfish Pollution Model component of the Puget Sound

Ecosystem Portfolio Model.

7. Photographs of examples of a bluff-backed beach and a barrier beach on Puget Sound, Washington.

8. Cumulative effects analysis of Puget Sound, Washington, shoreline armoring using a geometric network in ArcGIS 9.3.

9. ENVISION armoring projections for the South Central Puget Sound Subbasin used in the Puget Sound Ecosystem Portfolio Model.

10. Photograph of Bainbridge Island, Washington.

11. Map showing 10 field validation sites in east Kitsap County, Washington, including Bainbridge Island, used for statistics-based development of the Beach Armoring Index. .....29

12. Map of Bainbridge Island predicted ordered logistic regression predictions based on full model set beach scores.

13. Demand function relating the visitation rate (number of visits per 1,000 individuals in population) to mean travel distance from zip code origins to Washington State parks within Puget Sound.

14. Beach Armoring Index scores at forage-fish spawning beaches by Puget Sound subbasin in the Puget Sound Ecosystem Portfolio Model-year 2000 baseline data.

15. Change in Beach Armoring Index scores at forage-fish spawning beaches by Puget Sound subbasin from 2000 to 2060 under the Unconstrained Growth scenario in the Puget Sound Ecosystem Portfolio Model. Under the

16. An intersection of Beach Armoring Index scores in the Puget Sound Ecosystem Portfolio Model and recreational visits at Washington State beaches, classified by access type. 


\section{Tables}

1. PSEPM sub-models and relationship to Puget Sound valued ecosystem components (VECs) and ecosystem services

2. Negative binomial regression results for predicted fecal coliform bacteria counts used in the Shellfish Pollution Model component of the Puget Sound Ecosystem Portfolio Model......11

3. Beach Armoring Index variable scores, based on data distributions, used in the Puget Sound Ecosystem Portfolio Model.

4. Average Beach Armoring Index score used in the Puget Sound Ecosystem Portfolio Model, by scenario, year, and subbasin.

5. Eight variations of the Beach Armoring Index used in the Puget Sound Ecosystem Portfolio Model.

6. Beach Armoring Index variable definitions and scores used in the Beach Armoring Index sensitivity analysis.

7. Field validation scores for the Beach Armoring Index based on a field assessment method developed by Borde and others (2009).

8. Beach Armoring Index scores and correlation with field validation data used in the Puget Sound Ecosystem Portfolio Model.

9. Ordered logistic regression results for the full model set and metric subset B

10. Classification accuracy of scores from the complete model set and metric subset $B$ based on ordered logistic regression results.

11. Summary statistics for all Recreational Visitation Model data from 57 Washington State parks.

12. Results from the Recreational Visitation Model (negative binomial (NB) and zerotruncated negative binomial models ) component of the Puget Sound Ecosystem Portfolio model. 


$\begin{array}{ll}\text { Acronyms Used in This Report } \\ \text { BLB } & \text { Bluff-backed beach } \\ \text { CGS } & \text { Coastal Geologic Services, Inc. } \\ \text { DEM } & \text { Digital elevation model } \\ \text { DOH } & \text { Washington State Department of Health } \\ \text { DU } & \text { Drainage unit } \\ \text { EPM } & \text { Ecosystem Portfolio Model } \\ \text { FB } & \text { Feeder bluff } \\ \text { FBE } & \text { Feeder bluff exceptional } \\ \text { GIS } & \text { Geographic information system } \\ \text { LULC } & \text { Land use/land cover } \\ \text { MA } & \text { Millennium Ecosystem Assessment } \\ \text { MG } & \text { Managed Growth (scenario) } \\ \text { NB } & \text { Negative binomial } \\ \text { NLCD } & \text { National Land Cover Database } \\ \text { NHD+ } & \text { National Hydrography Dataset } \\ \text { PA } & \text { Population availability } \\ \text { PSEPM } & \text { Puget Sound Ecosystem Portfolio Model } \\ \text { PSNERP } & \text { Puget Sound Nearshore Ecosystem Restoration Project } \\ \text { PSP } & \text { Puget Sound Partnership } \\ \text { SPARROW } & \text { Spatially Referenced Regressions On Watershed attributes } \\ \text { SWAN } & \text { Simulating WAves Nearshore } \\ \text { SQ } & \text { Status Quo (scenario) } \\ \text { TCM } & \text { Travel cost method } \\ \text { UG } & \text { Unconstrained Growth (scenario) } \\ \text { USEPA } & \text { U.S. Environmental Protection Agency } \\ \text { USGS } & \text { U.S. Geological Survey } \\ \text { VEC } & \text { Valued ecosystem component } \\ \text { WDFW } & \text { Washington Department of Fish and Wildlife } \\ \text { ZTNB } & \text { Zero-truncated negative binomial } \\ & \end{array}$




\section{Acknowledgments}

The authors would like to acknowledge the Web-site developer for the Puget Sound Ecosystem Portfolio Model, Michael Gould (U.S. Geological Survey (USGS) Western Geographic Science Center) and the programming contributions of Peter $\mathrm{Ng}$ (USGS Western Geographic Science Center) for the Beach Armoring Index model. Dr. John Bolte and Dr. Kellie Vache (Oregon State University) generated ENVISION data on growth scenarios, which were used as inputs for our models. We thank Dr. Guy Gelfenbaum (USGS Pacific Coastal and Marine Science Center), Hugh Shipman (Washington Department of Ecology), and James Johannessen (Licensed Engineering Geologist) for their advice on the development of the Beach Armoring Index. We thank Dr. David Finlayson (USGS Pacific Coastal and Marine Science Center) for the use of his fetch length calculation script and John Foster for data generation and analysis. We also thank Dr. Ronald Thom and Chaeli Judd (Pacific Northwest National Laboratory) for the use of their Controlling Factors Model field validation method. We thank Greg Coombs, Ashley Scott, Scott Kellogg, and Tim Determan (Washington Department of Health Office of Shellfish and Water Protection) for providing us with the water-quality data used to develop the Shellfish Pollution Model. We thank Dr. Michael Papenfus (Stanford University) for many comments on the recreational visitation analysis, Bill Koss (Washington State Parks) for providing visitation data, and Camille Speck (Washington Department of Fish and Wildlife) for recreational shellfish harvest data. Jessica Bennet and Jan Jacobs (Washington Department of Ecology) helped by contributing data from the BEACH program, and Dr. Mark Plummer (NOAA) provided insights useful for the recreational visitation analysis. This project was funded by the U.S. Environmental Protection Agency under Interagency Agreement IADW14.95762701 and the USGS Geographic Analysis and Monitoring Program. Finally we thank our reviewers, Will Forney and Laura Norman for improvements made to this report. 


\title{
Tools for Evaluating and Refining Alternative Futures for Coastal Ecosystem Management-the Puget Sound Ecosystem Portfolio Model
}

\author{
By Kristin B. Byrd, Jason R. Kreitler, and William B. Labiosa
}

\begin{abstract}
The U.S. Geological Survey Puget Sound Ecosystem Portfolio Model (PSEPM) is a decision-support tool that uses scenarios to evaluate where, when, and to what extent future population growth, urban growth, and shoreline development may threaten the Puget Sound nearshore environment. This tool was designed to be used iteratively in a workshop setting in which experts, stakeholders, and decisionmakers discuss consequences to the Puget Sound nearshore within an alternative-futures framework. The PSEPM presents three possible futures of the nearshore by analyzing three growth scenarios developed out to 2060: Status Quo - continuation of current trends; Managed Growth - adoption of an aggressive set of land-use management policies; and Unconstrained Growth - relaxation of land-use restrictions. The PSEPM focuses on nearshore environments associated with barrier and bluff-backed beaches - the most dominant shoreforms in Puget Sound - which represent 50 percent of Puget Sound shorelines by length. This report provides detailed methodologies for development of three submodels within the PSEPM - the Shellfish Pollution Model, the Beach Armoring Index, and the Recreation Visits Model. Results from the PSEPM identify where and when future changes to nearshore ecosystems and ecosystem services will likely occur within the three growth scenarios. Model outputs include maps that highlight shoreline sections where nearshore resources may be at greater risk from upland land-use changes. The background discussed in this report serves to document and supplement model results displayed on the PSEPM Web site located at http://geography.wr.usgs.gov/pugetSound/index.html.
\end{abstract}

\section{Introduction}

The U.S. Geological Survey (USGS) Puget Sound Ecosystem Portfolio Model (PSEPM) is a decision-support tool that uses scenarios to evaluate where, when, and to what extent future population growth, urban growth and shoreline development may threaten the Puget Sound nearshore environment. The PSEPM focuses on nearshore environments associated with barrier and bluff-backed beaches - the most dominant shoreforms in Puget Sound - which represent 50 percent of Puget Sound shorelines by length. The PSEPM builds on approaches used in the South Florida Ecosystem Portfolio Model (Labiosa and others, 2009), which used place-based scenarios and models. Both 
the PSEPM and the South Florida models use multiple criteria to evaluate scenarios of ecosystem-services changes, and provide results through a Web-based interface. Within the Puget Sound model, a suite of submodels identify multiple connections between land use and the nearshore's capacity to support ecosystems that provide edible shellfish, swimmable beaches and fishable waters, recreational opportunities, and many other activities and environments that people value.

Puget Sound has been designated as an "estuary of national significance" by the U.S. Environmental Protection Agency's National Estuary Program, and is substantially impaired in terms of water quality, habitat degradation, and endangered species, among other issues. Several major restoration efforts are underway, including large efforts led by the Puget Sound Partnership (PSP, the Washington State lead for Puget Sound restoration) and the Puget Sound Nearshore Ecosystem Restoration Project (PSNERP, the combined Federal/State effort led by the U.S. Army Corps of Engineers and the Washington Department of Fish and Wildlife).

\section{Ecosystem Services and Valued Ecosystem Components (VECs)}

Ecosystem services are the benefits people obtain from ecosystems (Millennium Ecosystem Assessment, 2005). These include provisioning services such as shellfish and agricultural products, regulating services such as erosion control and carbon sequestration; cultural services such as spiritual, recreational, and cultural benefits; and supporting services such as nutrient cycling, primary productivity, and provision of habitats. Valued ecosystem components (VECs) are key elements of PSNERP restoration planning efforts. The goal of this project is the restoration of natural biophysical processes that create and maintain nearshore ecosystem structure and function (Greiner, 2010). For example, one of these processes is restoring sediment sources to beaches to restore habitats that support species that historically thrived in Puget Sound. VECs were selected by the PSNERP's Puget Sound Nearshore Science Team to communicate the value and priorities of nearshore restoration to managers and the public.

\section{Puget Sound Growth Scenarios Through 2060}

Within the context of ecosystem services and priorities of VECs, the PSEPM explores the implications of future regional growth and development, including shoreline modifications, to Puget Sound. The growth scenarios evaluated in this report were developed by PSNERP as part of their Future Risk Assessment Project. The purpose of this project was to explore the future level of impairment of the Puget Sound nearshore if PSNERP is not implemented, using a scenario-based approach to account for the very large uncertainties involved in such an assessment. These decadal scenarios are modeled out to 2060 by the geographic information system (GIS) based ENVISION model (http://envision.bioe.orst.edu/StudyAreas/PugetSound/) developed at Oregon State University (Bolte and Vache, 2010). The three scenarios (discussed in detail at http://envision.bioe.orst.edu/studyareas/pugetsound/) include:

1. Status Quo-continuation of current trends,

2. Managed Growth - adoption of an aggressive set of land-use management policies and concentrating growth within fixed urban growth areas, and

3. Unconstrained Growth - relaxation of land-use restrictions and more growth occurring outside urban growth areas.

We emphasize that a scenario is not a prediction. Instead it represents a plausible account of the future given logical assumptions about how conditions may change over 
space and time (Peterson and others, 2003). Because other assumptions may be similarly plausible with very different implications for the future, scenarios can be used to explore the potentially very large uncertainties involved in regional change. Scenario planning is most useful in cases such as long-term planning for the Puget Sound region, where uncertainty is high, the future is unknown, and the ability to control the system is relatively low, due to the presence of difficult-to-control system drivers like land-use change, human attitudes toward ecosystem restoration, and climate change and other related impacts.

The PSEPM leveraged earlier non-spatial scenarios developed for PSNERP by Marina Alberti at the University of Washington (Alberti, 2009). These scenarios were based on storylines influenced by two key drivers of change - climate and population. The spatially explicit ENVISION scenarios were developed in part using information from the Alberti scenarios. We modeled changes to Puget Sound nearshore VECs and ecosystem services on the basis of these ENVISION scenarios.

The PSEPM is to be used iteratively in a facilitated collaborative group process in which experts, stakeholders, and decisionmakers meet in workshop settings to discuss consequences to the Puget Sound nearshore within an alternative futures framework. Model outputs include maps that highlight shoreline sections where nearshore resources may be at greater risk from upland land-use changes. Using these results, planners may focus threat-reduction strategies to targeted areas to meet Puget Sound-wide conservation and restoration goals.

In the following sections, this report provides detailed methodologies for development of submodels within the PSEPM. The report also provides results of scenarios analyses in which each submodel was used to compare how nearshore resources may change under the three ENVISION growth scenarios. Furthermore, the background it provides serves to document and supplement model results displayed on the PSEPM Web site at http://geography.wr.usgs.gov/pugetSound/index.html.

\section{Overview of the Puget Sound Ecosystem Portfolio Model}

This section of the report provides an overview of the PSEPM. It includes a brief description of the PSEPM submodels and the PSEPM Web-enabled data visualization tool.

\section{PSEPM Submodels}

Three submodels within PSEPM compare the urban growth scenarios discussed above. These include:

1. Shellfish Pollution Model — estimates fecal coliform bacteria concentrations in commercial shellfish growing areas based on scenarios of land-cover change in watersheds that drain to Puget Sound (http://geography.wr.usgs.gov/pugetSound/pathMap.html).

2. Beach Armoring Index - scores beaches based on the potential for geomorphological and ecological changes due to scenarios of cumulative armoring onsite and updrift of a given beach (http://geography.wr.usgs.gov/pugetSound/beachMap.html).

3. Recreation Visits Model - models changes in State Park beach visitation based on scenarios of population distributions in Puget Sound (http://geography.wr.usgs.gov/pugetSound/recMap.html). The Shellfish Pollution Model and the Beach Armoring Index describe potential changes to beach condition - water quality and geomorphology and habitat (fig. 1). Results from these models and the Recreation Visits model influence potential changes to nearshore resources, including ecosystem goods and services and VECs. The PSEPM 
portrays potential future changes to forage-fish spawning habitat, recreational shellfish harvesting, and recreational beach quality by intersecting models with existing data, such as the presence of forage-fish spawning beaches (table 1).

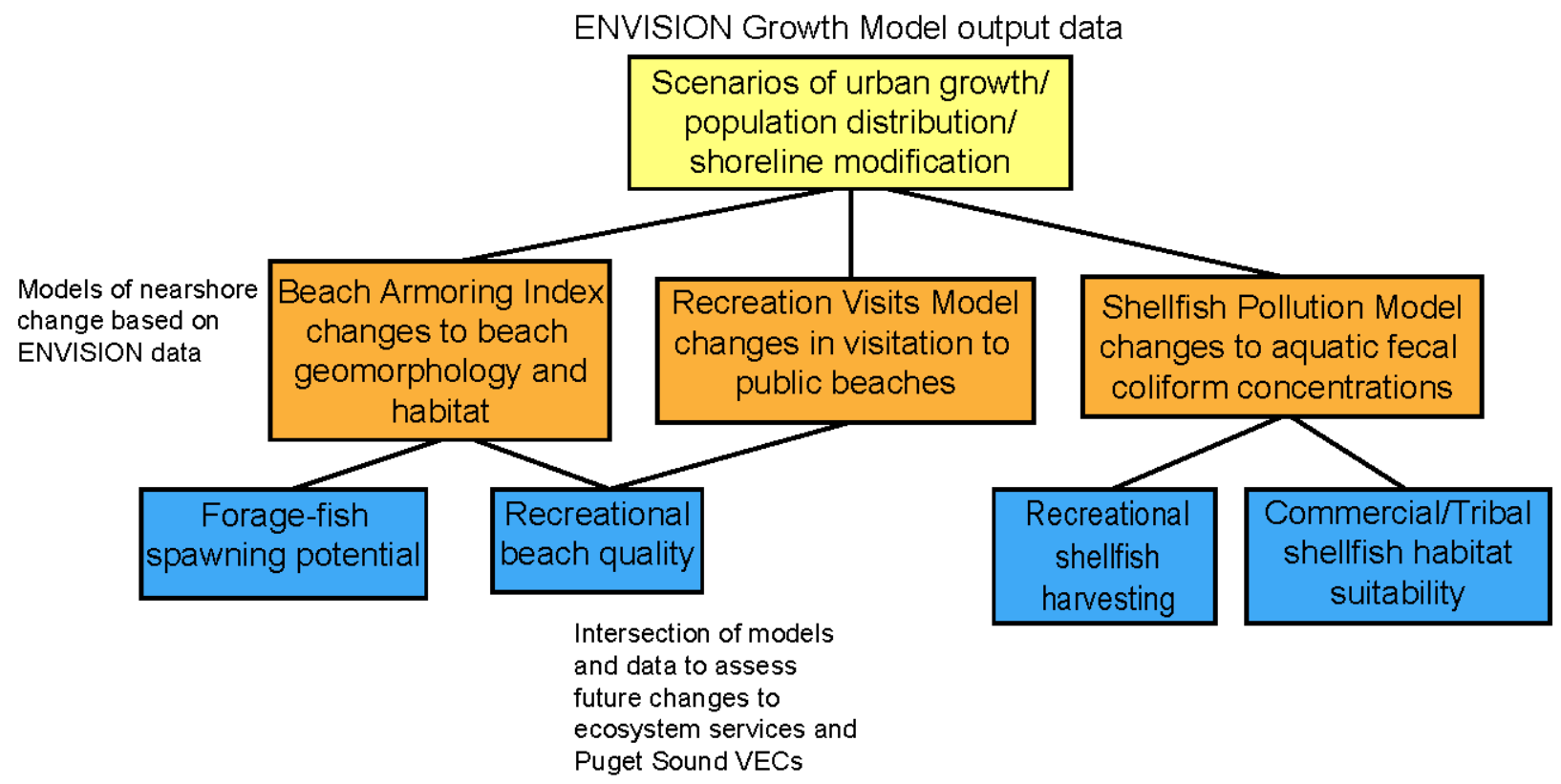

Figure 1. The Land-Water-Human Connection-Changes to metrics of nearshore condition under alternative growth scenarios. Scenarios of future growth (yellow box) interact with models of nearshore change (orange boxes) to produce output that assesses future changes to ecosystem services (blue boxes). The submodels may affect different ecosystem services-for example, Beach Armoring Index results affect both forage-fish spawning and recreational beach quality (together with the Recreation Visits model results). 
Table 1. PSEPM sub-models and relationship to Puget Sound valued ecosystem components (VECs) and ecosystem services.

\begin{tabular}{lll}
\hline PSEPM Submodel & \multicolumn{1}{c}{ Model description } & \multicolumn{1}{c}{$\begin{array}{c}\text { Ecosystem service } \\
\text { (Millenium Ecosystem Assessment, } \\
\text { 2005) }\end{array}$} \\
\hline \multicolumn{1}{c}{ Native Shellfish VEC } & \\
\hline $\begin{array}{l}\text { Shellfish } \\
\text { Pollution Model }\end{array}$ & $\begin{array}{l}\text { Statistical model based on land cover and } \\
\text { Washington Dept. of Health water-quality data in } \\
\text { commercial shellfish growing areas. }\end{array}$ & $\begin{array}{l}\text { Provisioning services: food. } \\
\text { Cultural services: ethical values. } \\
\text { Regulating services: water } \\
\text { purification. }\end{array}$ \\
$\begin{array}{l}\text { Recreational } \\
\text { shellfish } \\
\text { harvesting }\end{array}$ & $\begin{array}{l}\text { Shellfish pollution model results intersected with } \\
\text { Washington Dept. of Fish and Wildlife annual } \\
\text { harvest data at recreational shellfish beaches. }\end{array}$ & $\begin{array}{l}\text { Provisioning services: food. } \\
\text { Cultural services: recreation and } \\
\text { ecotourism. }\end{array}$ \\
\hline \multicolumn{1}{c}{ Beaches and bluffs VEC } \\
$\begin{array}{l}\text { Beach Armoring } \\
\text { Index }\end{array}$ & $\begin{array}{l}\text { Index based on Puget Sound Nearshore Ecosystem } \\
\text { Restoration Project change analysis geodatabase and } \\
\text { fetch data. }\end{array}$ & $\begin{array}{l}\text { Cultural services: existence values, } \\
\text { recreation and ecotourism. } \\
\text { Regulating services: erosion } \\
\text { regulation. }\end{array}$ \\
$\begin{array}{l}\text { Recreation Visits } \\
\text { Model }\end{array}$ & $\begin{array}{l}\text { Statistical model based on Washington State Park's } \\
\text { visitation data. }\end{array}$ & $\begin{array}{l}\text { Cultural services: recreation and } \\
\text { ecotourism }\end{array}$ \\
$\begin{array}{l}\text { Recreational } \\
\text { beach quality }\end{array}$ & $\begin{array}{l}\text { Beach Armoring Index intersected with Recreation } \\
\text { visits model results and beach access type. }\end{array}$ & $\begin{array}{l}\text { Cultural services: existence values, } \\
\text { recreation, and ecotourism. } \\
\text { Regulating services: erosion } \\
\text { regulation. }\end{array}$ \\
\hline
\end{tabular}

Forage-fish VEC

\begin{tabular}{lll}
\hline $\begin{array}{l}\text { Forage-fish } \\
\text { spawning } \\
\text { potential }\end{array}$ & $\begin{array}{l}\text { Washington Dept. of Fish and Wildlife (WDFW) } \\
\text { 2009 data and WDFW and U.S.Geological Survey } \\
\text { modeling collaboration, intersected with Beach } \\
\text { Armoring Index. }\end{array}$ & $\begin{array}{l}\text { Provisioning services: food. } \\
\text { Cultural services: existence values. }\end{array}$ \\
\hline
\end{tabular}

\section{PSEPM Web-Enabled Data Visualization}

To provide an opportunity for users to view model results and compare scenarios, a Web application was designed for the PSEPM Web site. Web-based GIS (WebGIS) applications are practical tools for an audience to view and compare spatial data without the need for specialized GIS software. The PSEPM Web site was designed for stakeholders, scientists, and policymakers in the Puget Sound region. The main feature of the WebGIS is the design of a three-map viewer, which allows the user to view, compare, and contrast results of submodels described in table 1 and figure 1 at the data-point scale or the regional scale across three scenarios simultaneously (fig. 2). For each of the three submodels - Shellfish Pollution, Beach Armoring Index, and Recreation Visits - a "Compare Scenarios" page allows users to compare model results across scenarios for three representative time periods - year 2000, 2030, and 2060. A “Difference Maps" page allows users to view differences between scenarios for two time periods-2030 and 2060. An evaluation of changes to VECs or ecosystem services is made spatially explicit on the "Resource Impacts" page. This page provides scenario comparisons and difference maps for three analyses that intersect model results with nearshore social and ecological data- 
forage-fish habitat suitability, recreational shellfish harvesting, and recreational beach quality. Multiattribute icons were selected to illustrate how changes to nearshore conditions (that is, increased pollution) may influence an ecosystem service (that is, recreational shellfish harvesting opportunities). Model results can be downloaded from a data download page in $\mathrm{kml}$ format for users who would like to further investigate the data.

\section{PSEPM Submodels for Evaluating Alternative Futures}

In this section, the PSEPM submodels for evaluating alternative futures are further explained. The subsections focus on (1) the Shellfish Pollution Model and its methods, data, analysis, and results; (2) the Beach Armoring Index and its development considerations, explicit methods, results, and studies on Bainbridge Island for further development, analysis, field validation, and index comparison; and (3) the Recreation Visitation Model and its methods and results. This section also includes discussion of the models' synthesis to evaluate VECs and ecosystem services, which are related to foragefish spawning habitat, recreational shellfish beaches, and recreational beach quality.

\section{The Shellfish Pollution Model}

Shellfish are a culturally and economically valued ecosystem component in Puget Sound (Dethier, 2006). In Washington in 2005, commercial shellfish harvesting was a $\$ 97$ million industry (Chew and Toba, 2005), and more than 450,000 recreational shellfish licenses were sold (Puget Sound Action Team, 2007). For Native Americans, shellfish have always been a key domestic and commercial product and are used for subsistence, economic, and ceremonial purposes. Across the country, coastal urbanization has been closely correlated with contamination and closure of shellfish growing areas as a result of bacterial contamination (Glasoe and Christy, 2004). In Puget Sound's rural, shellfish-rich counties rapid population growth is increasing the risk for closures in commercial shellfish growing areas and recreational shellfish beaches (Washington State Office of Financial Management, 2002). Nonpoint source pollution is the most common cause of shellfish classification downgrades in Puget Sound, where commercially approved acreage has been reduced by 25 percent since 1980 (Puget Sound Action Team, 2002). Major contributors of nonpoint source pollution have been identified by the Puget Sound Action Team $(2000,2002)$ and the Washington State Department of Health (2004) and include failing onsite sewage systems, farm-animal wastes and stormwater runoff. For shellfish consumers, these pollutants increase the risk of disease from noroviruses and the hepatitis A virus (National Research Council, 1999). 


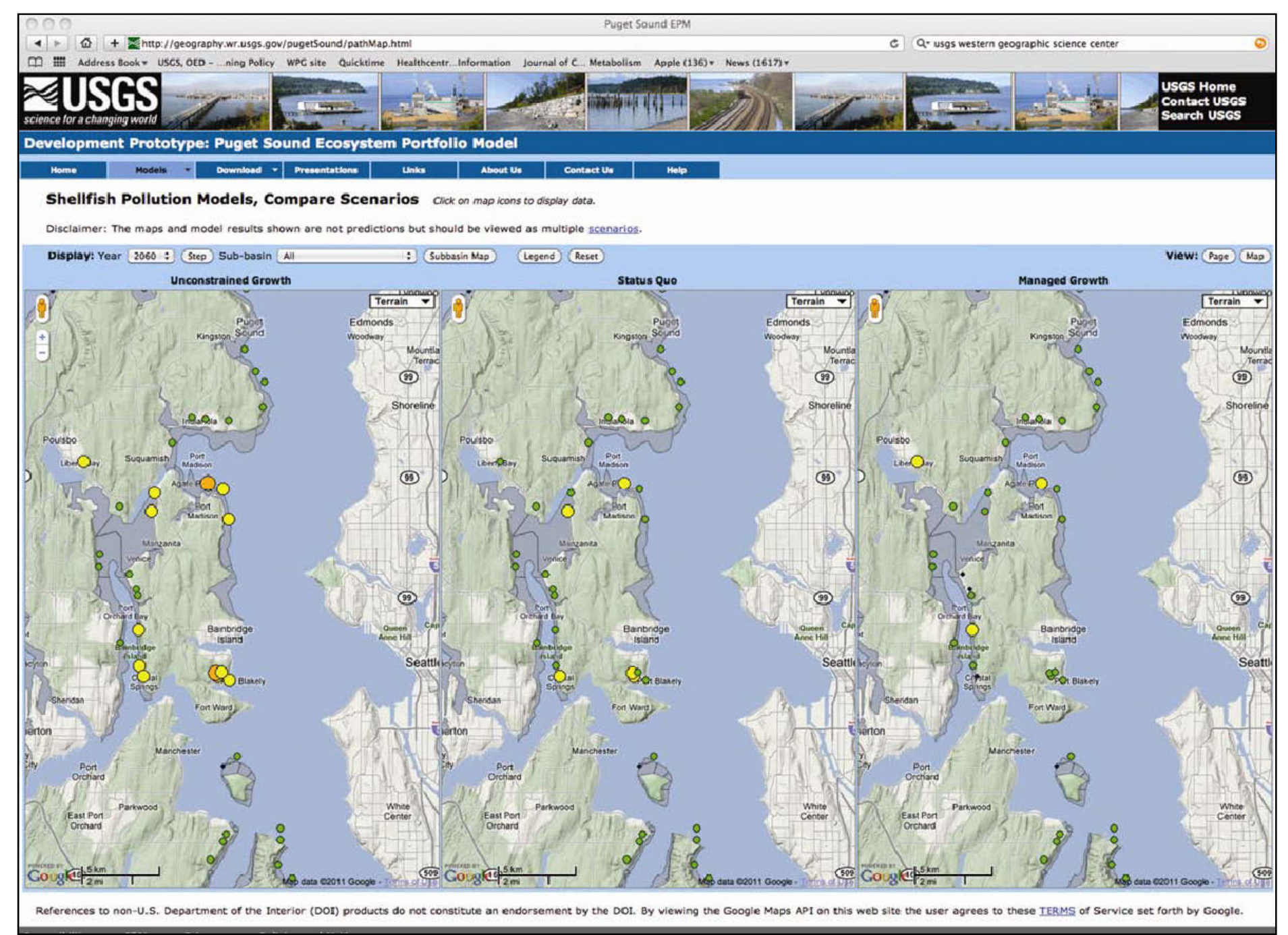

Figure 2 Three-map viewer in the Puget Sound Ecosystem Portfolio Model Web-based (WebGIS) application. This Web page displays Shellfish Pollution Model results for three scenarios in the year 2060. In the Unconstrained Growth scenario (left map), there are more locations where fecal coliform counts are likely higher (orange dots) than in the Status Quo or Managed Growth scenarios (middle and right maps). 
Given expected development patterns in watersheds with drainage conveyed to nearshore ecosystems, the Shellfish Pollution Model compares the ENVISION scenarios to determine which Puget Sound commercial shellfish growing areas are at greater risk of increased fecal coliform contamination within the next 50 years (fig. 3). This statistical model relates land cover within watersheds and environmental variables to fecal coliform bacteria concentration data collected by the Washington State Department of Health (DOH). Although fecal coliform bacteria are generally not harmful, their presence in high concentrations indicates that illness-causing pathogens may also be present (Glasoe and Christy, 2004).

\begin{tabular}{|c|c|c|c|c|}
\hline $\begin{array}{l}\text { Statistical model of } 2001 \\
\text { fecal coliform count data } \\
\text { based on } 2001 \text { land- } \\
\text { cover data, water } \\
\text { temperature and water } \\
\text { salinity }\end{array}$ & + & $\begin{array}{l}\text { Data from ENVISION } \\
\text { land-cover change } \\
\text { scenarios: } \\
\text { Managed Growth (MG) } \\
\text { Status Quo (SQ) } \\
\text { Unconstrained Growth } \\
\text { (UG) }\end{array}$ & $=$ & $\begin{array}{l}\text { Scenarios of fecal } \\
\text { coliform counts in } \\
\text { commercial shellfish } \\
\text { growing areas out to } \\
2060\end{array}$ \\
\hline
\end{tabular}

Figure 3. Diagram of shellfish pollution scenario analysis in the Puget Sound Ecosystem Portfolio Model. A statistical model was developed that relates 2001 fecal coliform count data to 2001 land-cover, water temperature and water salinity data. Land-cover change data from ENVISION model results served as input to the statistical model to develop scenarios of fecal coliform counts in shellfish growing areas out to 2060.

\section{Methods}

Data Sources

Water-quality data - Water-quality data on fecal coliform bacteria (count/100 ml) were obtained from the DOH Office of Shellfish and Water Protection. The DOH Office of Shellfish and Water Protection is responsible for evaluating commercial shellfish growing areas to determine their suitability for shellfish harvesting; suitability is classified as Approved, Conditionally Approved, Restricted, or Prohibited. Classification standards are derived from the National Shellfish Sanitation Program Guide for the Control of Molluscan Shellfish (Food and Drug Administration, 2009). For a growing area to be classified as Approved, marine water samples must meet a two-part waterquality standard:

1. Concentration of fecal coliform bacteria (the indicator organism) cannot exceed a geometric mean of 14 per $100 \mathrm{ml}$, and

2. The estimated $90^{\text {th }}$ percentile cannot exceed 43 organisms per $100 \mathrm{ml}$.

A minimum of 30 samples per water-quality station are used for these calculations. Each commercial growing area contains several water-quality stations, which are each sampled approximately 6 to 12 times a year. By the end of 2009, 1,488 water-quality stations had been established throughout Puget Sound. Data collected include raw fecal coliform counts, water salinity in parts per thousand, and water temperature data. No data exist in the urban corridor from Seattle to Tacoma, as shellfish harvesting is restricted there.

Watershed boundaries - Watershed boundaries were obtained from the PSNERP Change Analysis Geodatabase. Watersheds delineated at the PSNERP Drainage Unit 
scale were selected to define the watersheds draining into the nearshore of Puget Sound. This geodatabase was developed by the U.S. Army Corps of Engineers for planning Puget Sound ecosystem restoration (Anchor QEA, LLC, 2009; http://www.nws.usace.army.mil/PublicMenu/Menu.cfm? sitename=PSNERP\&pagename= Change_Analysis, accessed October 18, 2011). Drainage units were developed by creating drainage basins from a USGS 10-meter digital elevation model (DEM) and aggregating them in cases where numerous small drainages resulted. The average watershed size was $2.63 \mathrm{~km}^{2}$, with a minimum of $0.25 \mathrm{~km}^{2}$ and a maximum of 120.89 $\mathrm{km}^{2}$. Based on the presence of water-quality stations with sufficient data in the watershed's nearshore, a total of 335 watersheds were selected for analysis.

Watershed data-Land-cover data was obtained from the 2001 National Land Cover Dataset (NLCD), which was the baseline land cover used in the ENVISION model. Population data was obtained from Census 2000 block-group data (http://factfinder2.census.gov/faces/nav/jsf/pages/index.xhtml, accessed October 18, 2011), also the baseline population used in the ENVISION model. Slope data was derived from a USGS 10-meter DEM. Landscape metrics for Edge Density and Mean Perimeter-Area Ratio were derived from the NLCD using Patch Analyst 4, an ArcGIS extension for spatial analysis of landscape patches (Rempel, 2010). Watershed variables were calculated for two scales of analysis - the watershed scale and the stream scale. The stream scale was defined as the area within $90 \mathrm{~m}$ of a stream or canal/ditch mapped in the USGS National Hydrography Dataset Plus (NHD+) (http://nhd.usgs.gov/, accessed October 18, 2011).

1. Land-cover variables for the watershed scale included:

--Percent land cover of each land cover class, including impervious surfaces

--Population density

--Average slope

--Edge density for each forest, agricultural and developed NLCD class

--Mean perimeter-area ratio for each forest, agricultural and developed NLCD class

2. Land-cover variables for the stream scale included:

--Percent land cover of each land cover class, including impervious surfaces

--Average slope

Data Analysis

All water-quality stations located within watersheds at least $0.25 \mathrm{~km}^{2}$ in area were identified, and their station data from years 2000 to 2002 (corresponding with the 2001 NLCD) were combined into a single water-quality dataset. From this dataset, three dry season (April-October) and three wet season (November-March) data points from each water-quality station were randomly sampled. The geometric mean of all randomly selected samples within a watershed was calculated for use as a dependent variable (Alberti and Bidwell, 2005). A negative binomial regression method was applied in Stata 11, a statistical software program (StataCorp, 2009), to relate watershed variables and water-temperature and salinity data to fecal coliform count data. Negative binomial regression is a generalized linear model suitable for count data where its variance is much greater than the mean (the case with the DOH water-quality data). A backwardelimination regression analysis using a bootstrap method for standard error estimation was applied for the two scales of analysis - watershed and stream scales. 
Land-cover change data from ENVISION scenario model outputs were used to predict new fecal coliform counts by watershed, and standard errors of the predictions were also calculated. Predictions were made for each scenario and each decade, for a total of seven sets of predicted values. Differences in predicted fecal coliform counts were calculated for the following scenario comparisons: (1) Unconstrained Growth-Status Quo 2060, (2) Unconstrained Growth-Status Quo 2030, (3) Unconstrained GrowthStatus Quo 2030, (4) Unconstrained Growth-Managed Growth 2060, (5) Unconstrained Growth - Status Quo 2030, (6) Status Quo-Managed Growth 2030, and (7) Status Quo-Managed Growth 2060.

\section{Results}

Population density and NLCD development classes were removed from the analysis because they were collinear with impervious surface, which was retained in the analysis. A watershed-scale four variable model was found to have the best model fit (Wald $\mathrm{chi}^{2}$ test $=98.02, p=0.00, n=335$ ) (table 2). This means that given a sample size of 335 , there is a significant relationship between the independent variables and fecal coliform bacterial counts. Fecal coliform bacteria counts increased with higher percent cover impervious surface (fig. $4 A$ ) and higher water temperatures, and lower percent cover evergreen forest (fig. $4 B$ ) and lower water salinity.

Although model results are significant, much of the variance in the data is unexplained (pseudo $R^{2}=0.12$; fig. 5). In general, the statistical model under predicts bacteria counts for very high levels of actual counts. Based on ENVISION model scenario projections for evergreen forest cover and impervious surfaces, predicted fecal coliform counts across all subbasins and years tend to be higher when applying landcover data provided in the Unconstrained Growth scenario (fig. 6). Greater differences across scenarios were found in Bellingham Bay, Bainbridge Island, Hood Canal, and near Clallam Bay in the Strait of Juan de Fuca. In north central Puget Sound predicted fecal coliform counts tend to be higher in the Managed Growth scenario. One hypothesis for this result is that in the Managed Growth scenario development is concentrated within urban growth areas that are located near the shoreline, thereby increasing the risk for local water pollution. 
Table 2. Negative binomial regression results for predicted fecal coliform bacteria counts used in the Shellfish Pollution Model component of the Puget Sound Ecosystem Portfolio Model.

[Fecal coliform bacteria counts increased with higher percent cover impervious surface and higher water temperatures, and lower percent cover evergreen forest and lower water salinity. Each variable in the model is highly significant $(\mathrm{p}<0.05) . z=z$ test statistic, $P=$ probability, $\mathrm{ppt}=$ parts per thousand]

\begin{tabular}{lllcccc}
\hline & $\begin{array}{c}\text { Observed } \\
\text { coeffficient }\end{array}$ & $\begin{array}{c}\text { Bootstrap } \\
\text { standard error }\end{array}$ & $\mathbf{z}$ & $\mathbf{P > \mathbf { Z }}$ & $\begin{array}{c}\text { (95\% confidence } \\
\text { Interval) }\end{array}$ \\
\hline $\begin{array}{l}\text { Percent Cover } \\
\text { impervious }\end{array}$ & 0.025 & 0.011 & 2.280 & 0.022 & 0.004 & 0.047 \\
$\begin{array}{l}\text { surfaces } \\
\begin{array}{l}\text { Percent Cover } \\
\text { evergreen forest }\end{array}\end{array}$ & -0.004 & 0.002 & -2.610 & 0.009 & -0.007 & -0.001 \\
$\begin{array}{l}\text { Water salinity } \\
\text { (ppt) }\end{array}$ & -0.089 & 0.013 & -6.990 & 0.000 & -0.114 & -0.064 \\
$\begin{array}{l}\text { Water } \\
\text { temperature }\left({ }^{\circ} \mathrm{C}\right)\end{array}$ & 0.128 & 0.044 & 2.890 & 0.004 & 0.041 & 0.215 \\
Intercept & 2.211 & 0.600 & 3.680 & 0.000 & 1.035 & 3.388 \\
\hline
\end{tabular}

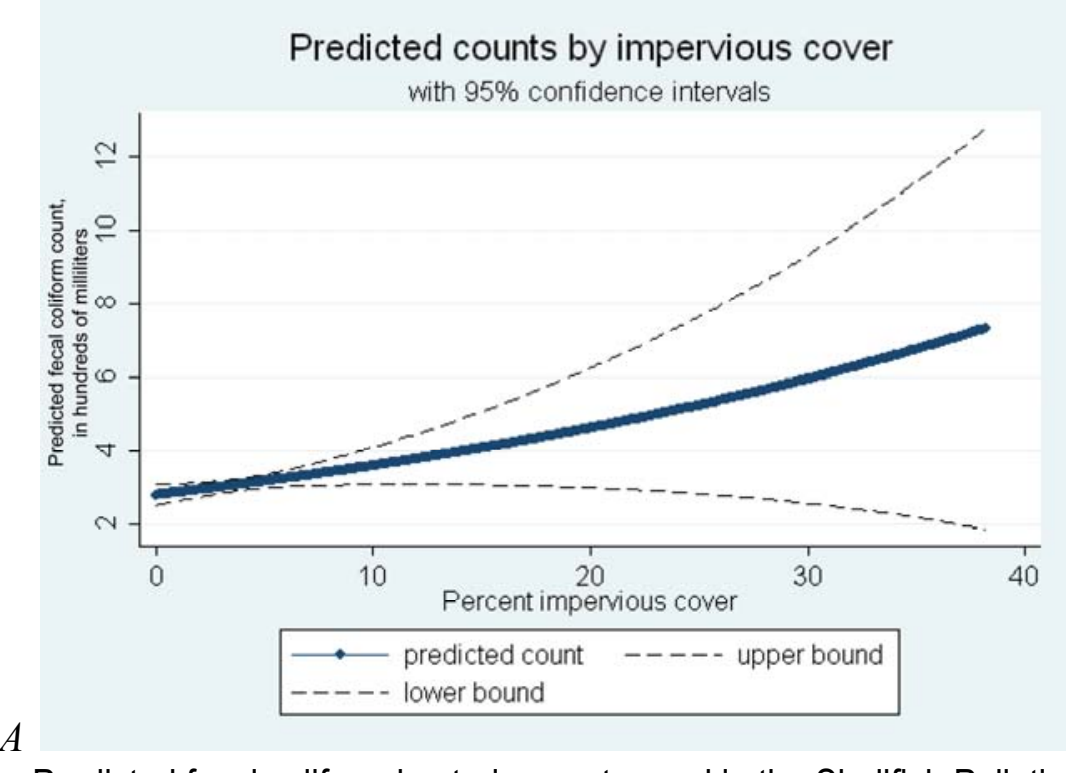

Figure 4. Predicted fecal coliform bacteria counts used in the Shellfish Pollution Model component of the Puget Sound Ecosystem Portfolio Model. $A$, Predicted counts by impervious cover holding other variables constant. $B$, Predicted counts by evergreen forest cover, holding other variables constant. 


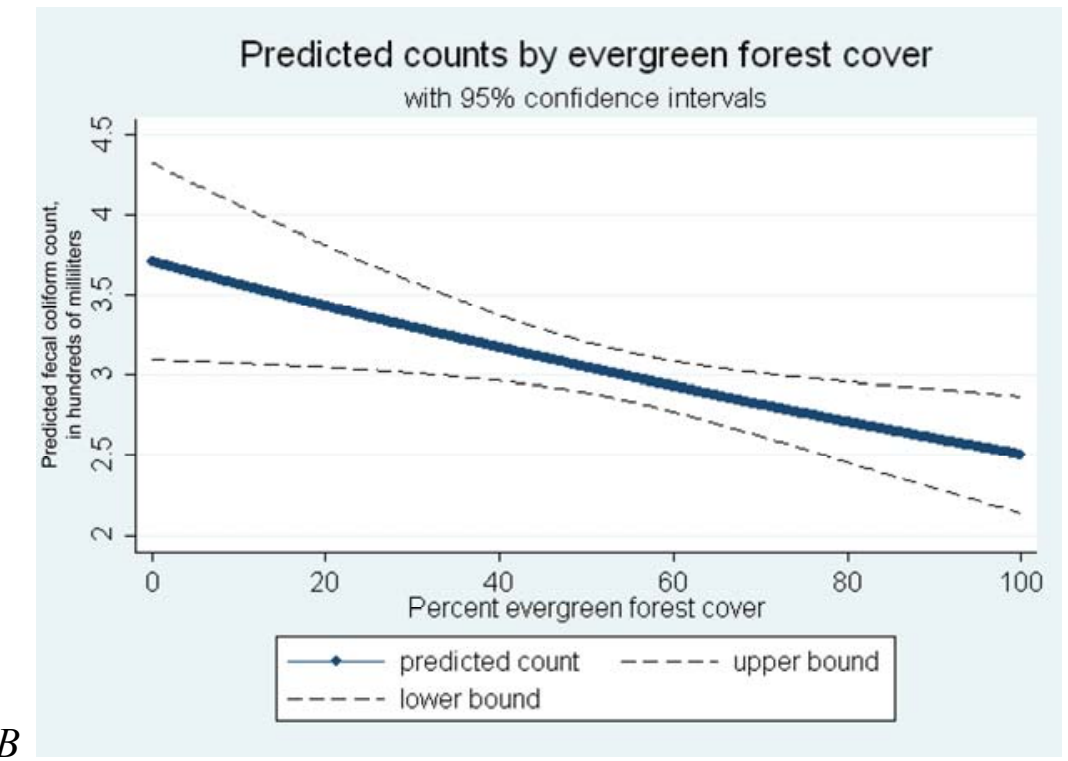

Figure 4. Continued.

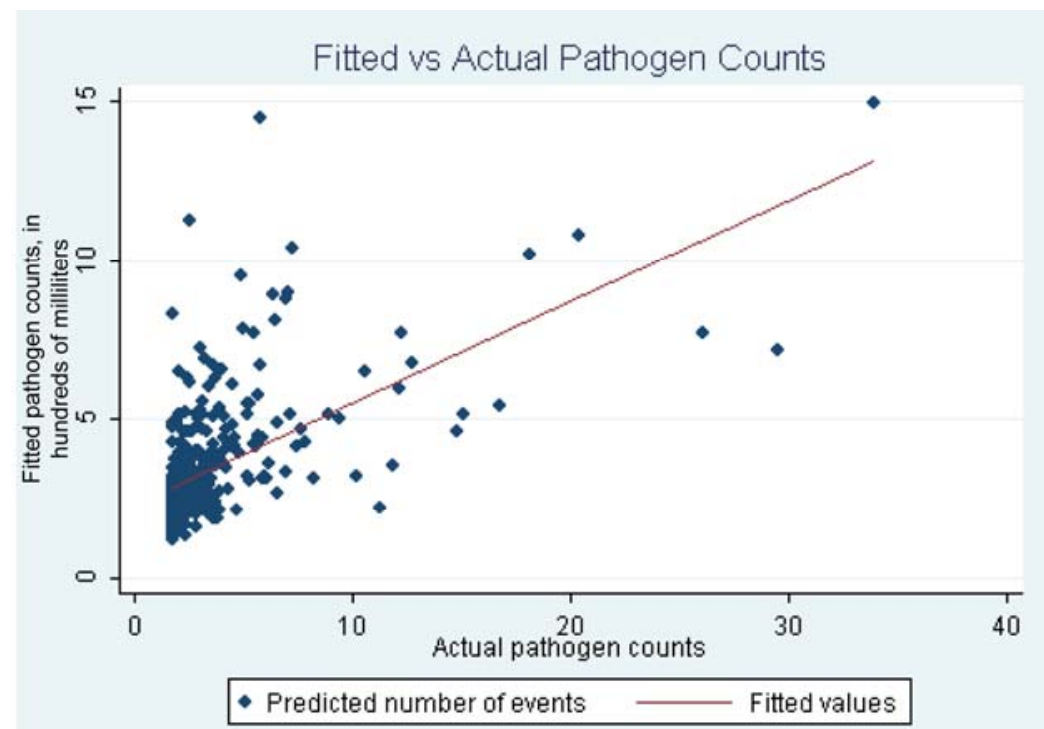

Figure 5. Fitted versus actual fecal coliform bacteria counts used in the Shellfish Pollution Model component of the Puget Sound Ecosystem Portfolio Model. As seen in the figure, the statistical model under predicts bacteria counts for very high levels of actual counts. 


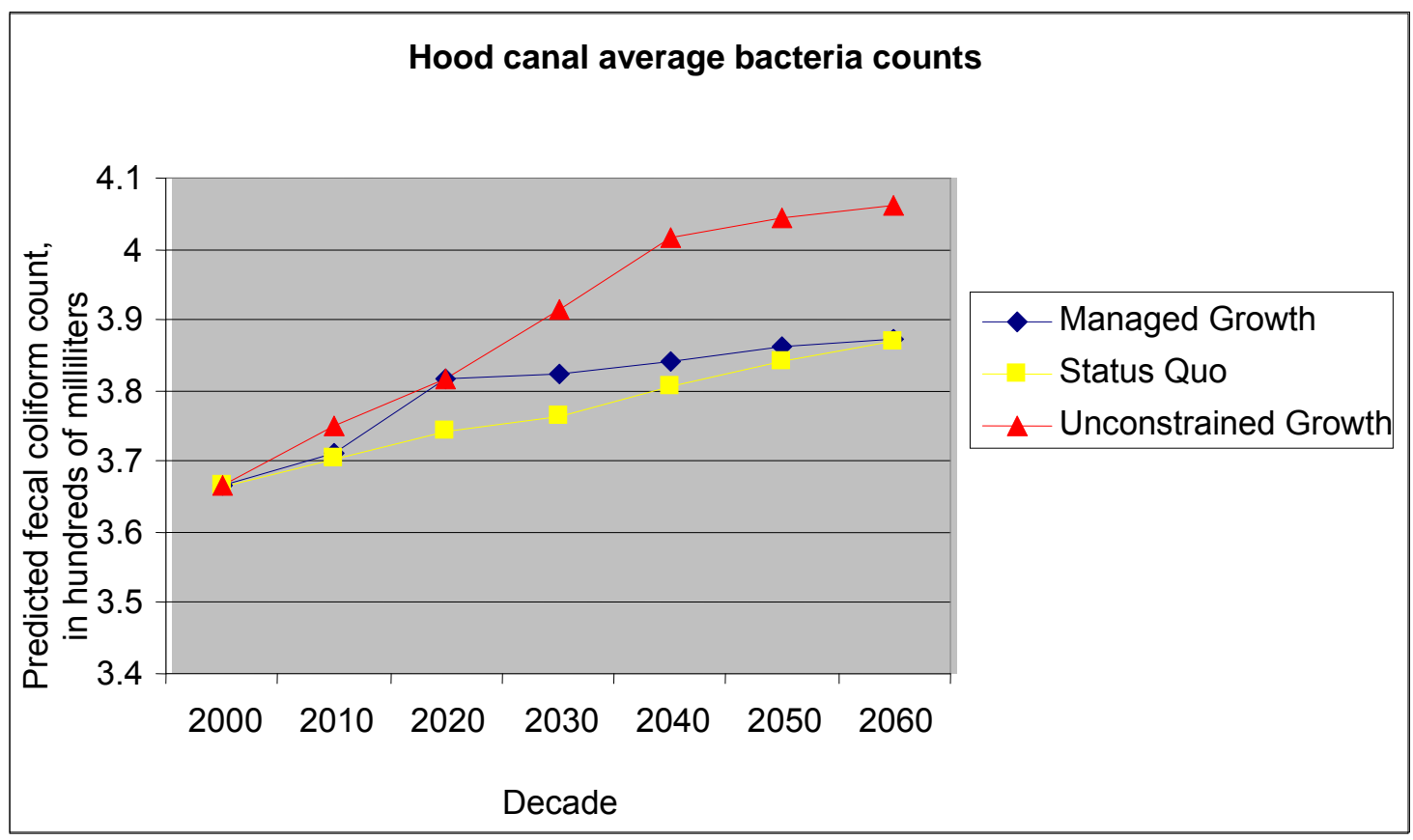

Figure 6. Average predicted fecal coliform bacteria count by subbasin and decade for each ENVISION scenario used in the Shellfish Pollution Model component of the Puget Sound Ecosystem Portfolio Model. In all subbasins except for north central Puget Sound, higher fecal coliform counts are expected in the Unconstrained Growth scenario.

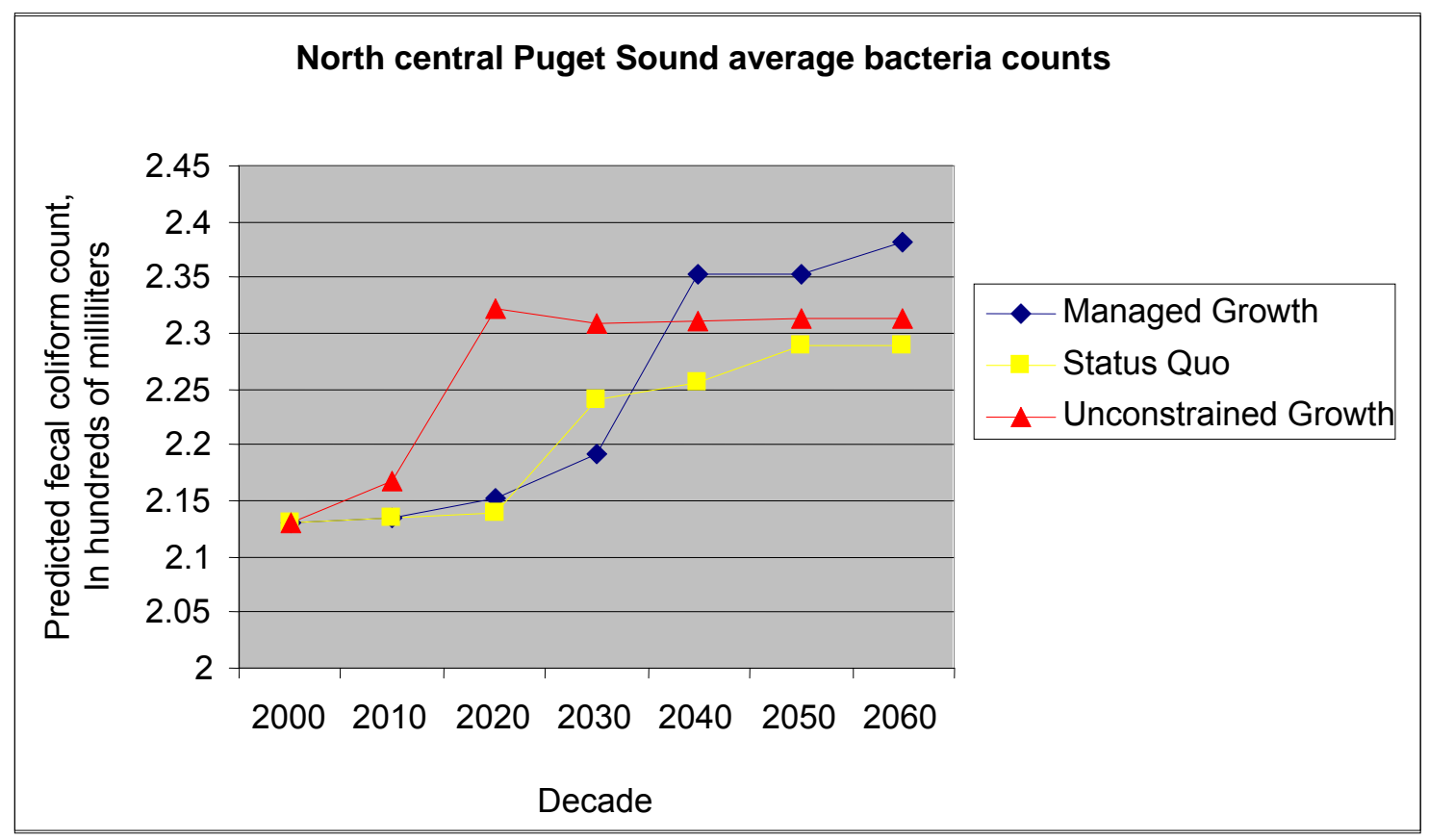

Figure 6ாسயா\&RQtinued. 


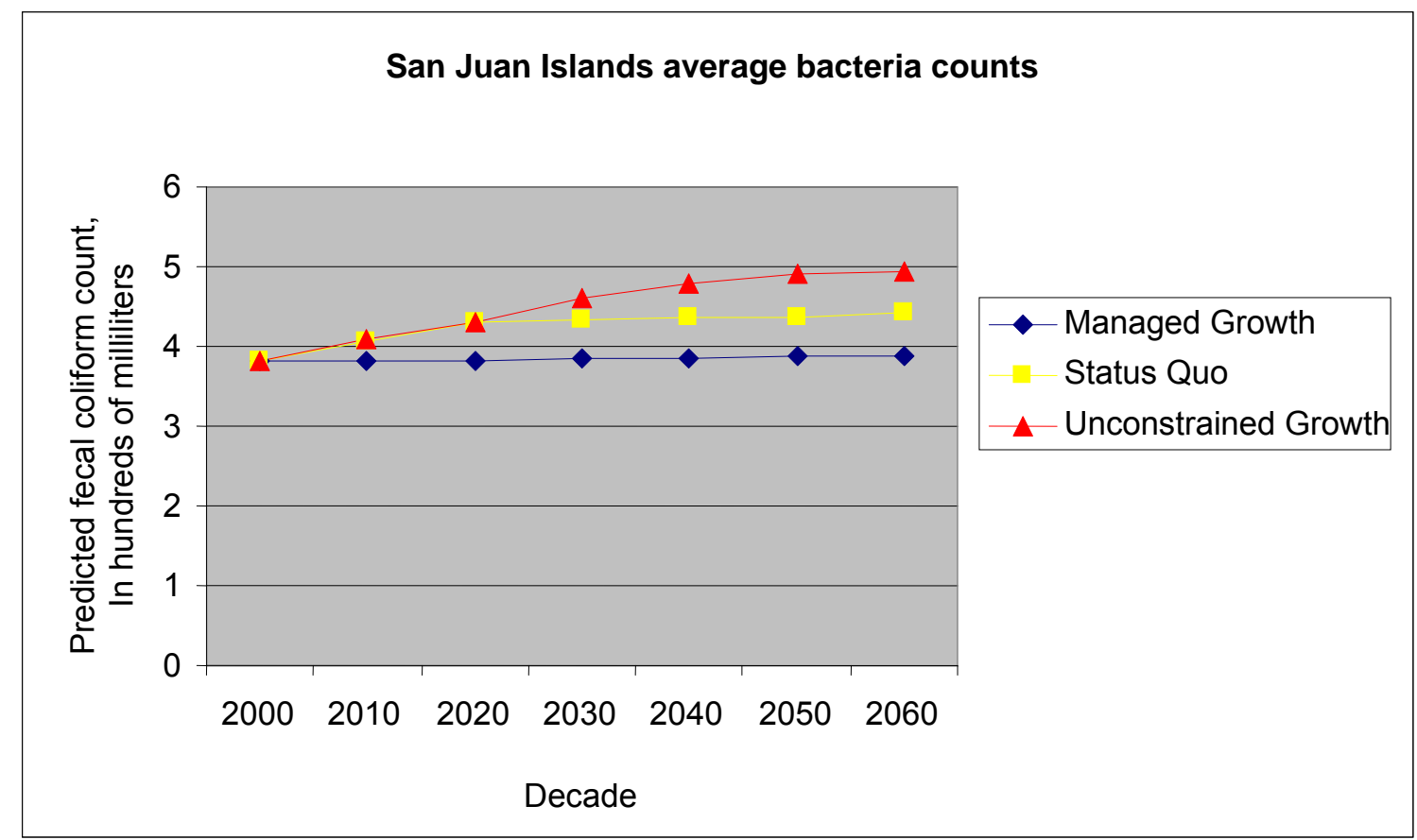

Figure 6ாسா\&Rinued.

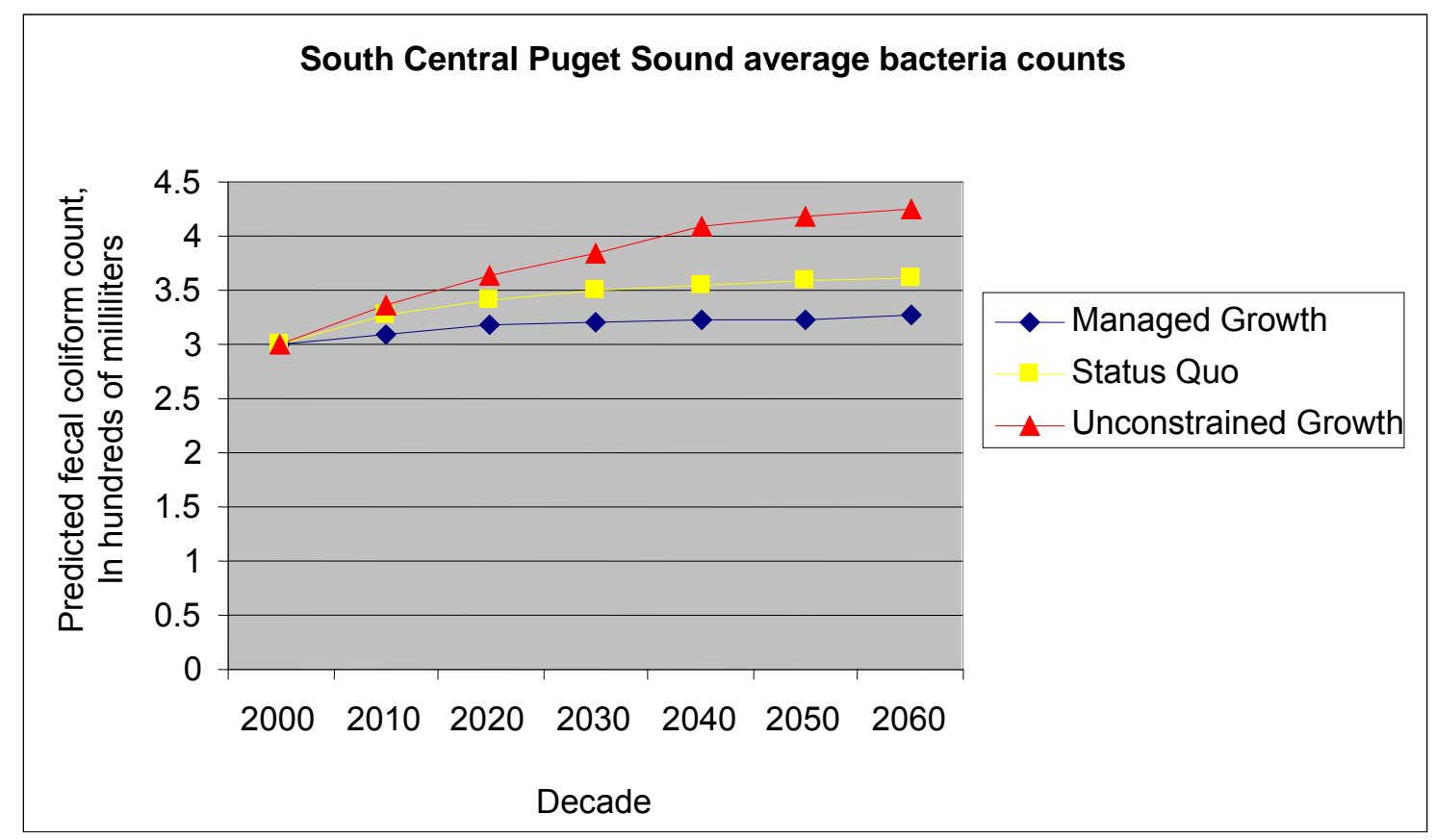

Figure 6माप्या \&ontinued. 


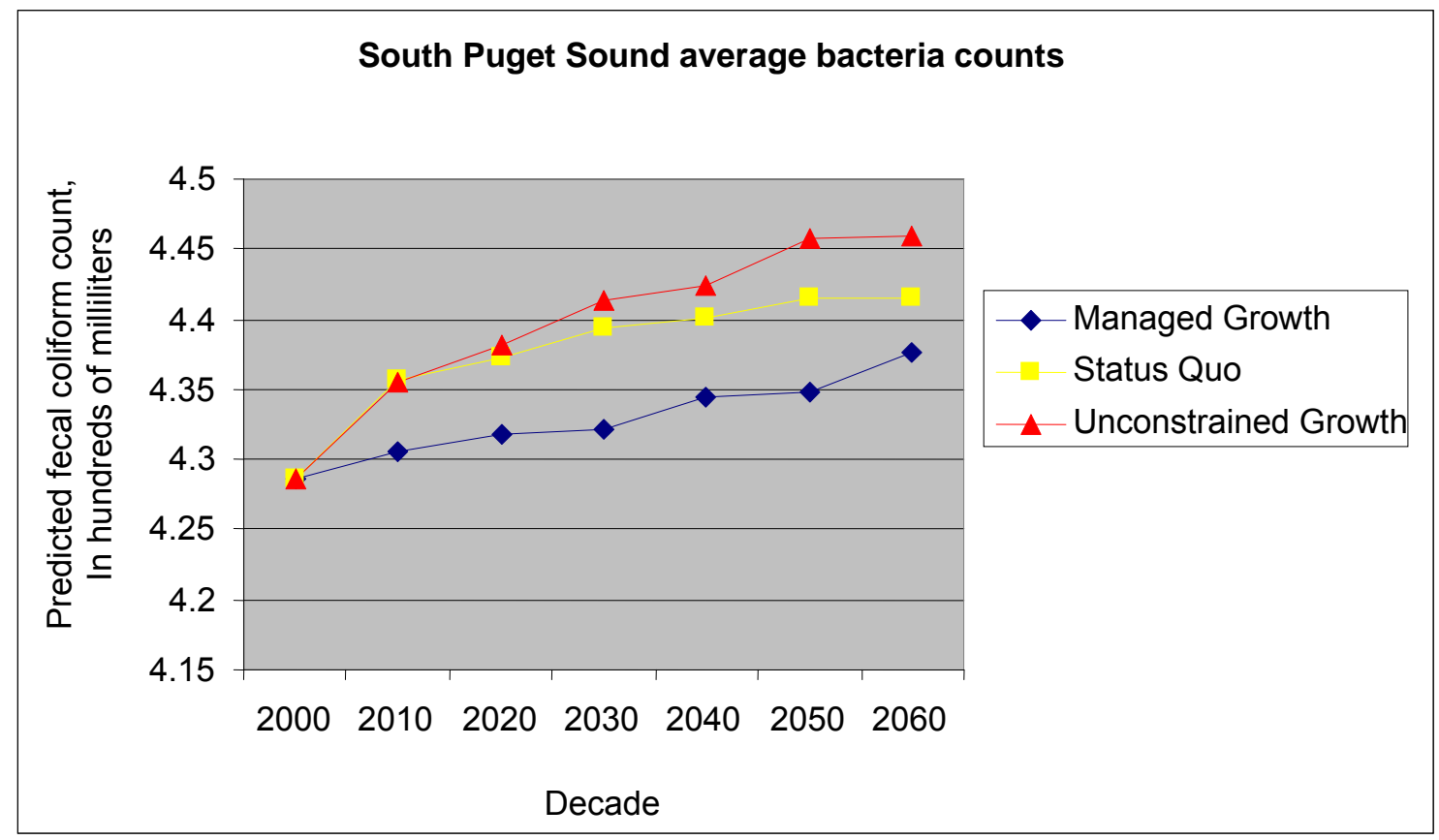

Figure 6ாس \&ontinued.

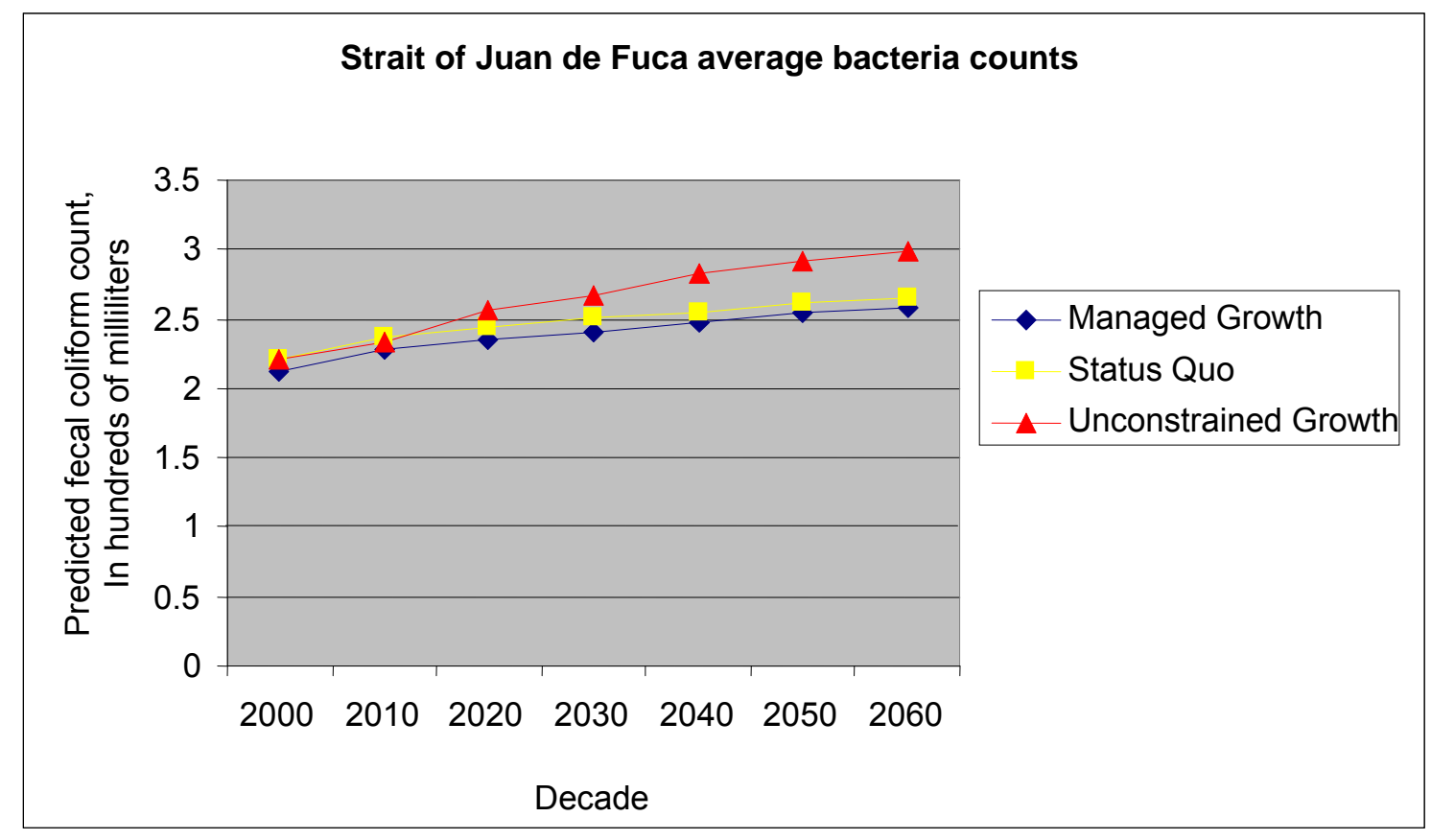

Figure 6ாणा \&ontinued. 


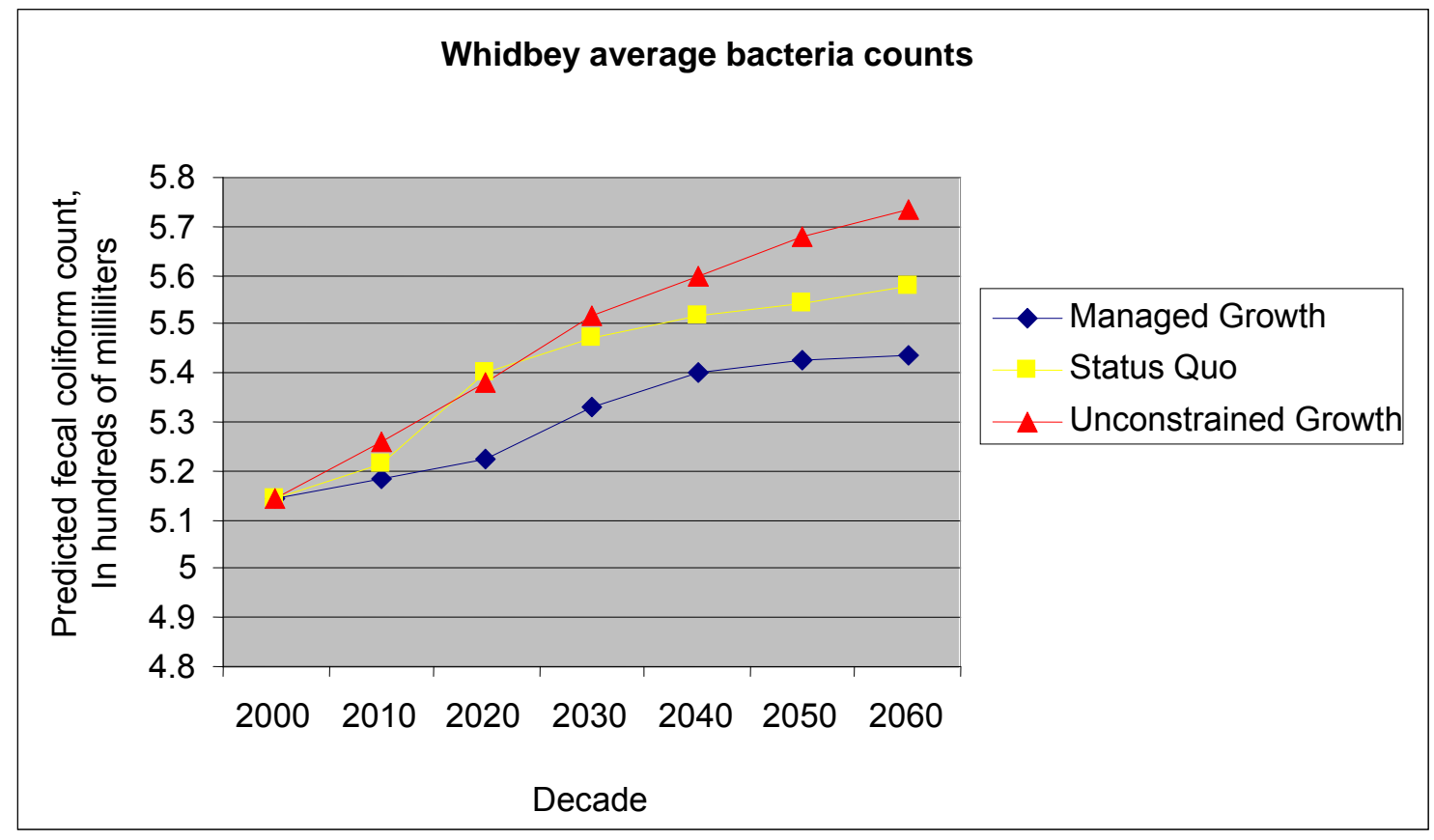

Figure 6ாس山\&ontinued.

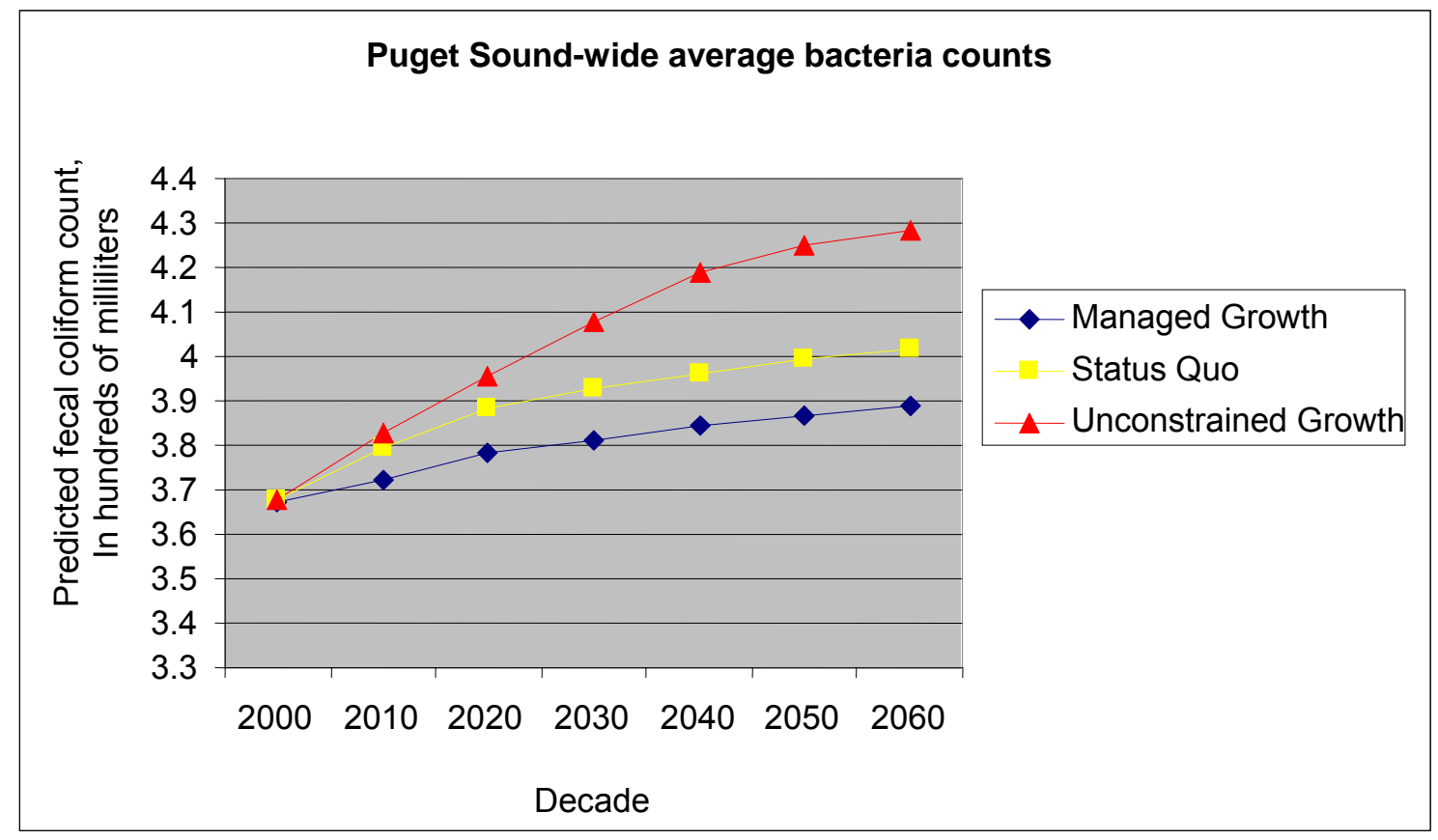

Figure 6ாயس\&ontinued.

Suggestions for Future Research

Studies relating coastal development to microbial contamination of shellfish growing areas must account for variability in climate and weather patterns, water circulation patterns, watershed hydrology and geology, land-cover and land-use patterns, pollution sources and management practices, and population densities and patterns (Glasoe and Christy, 2004). The model presented in the report is based on currently available data. To create a model that more closely relates land use to fecal coliform 
pollution, we recommend a more process-based approach, such as the use of the USGS SPARROW (Spatially referenced regressions on watershed attributes) model to model bacteria loading in freshwater streams and transport through the watershed (http://water.usgs.gov/nawqa/sparrow/, accessed October 18, 2011). In addition, the Washington Department of Ecology South Puget Sound Hydrodynamic Model of circulation and water quality could be used to estimate flushing time at water-quality stations, an important variable controlling fecal coliform counts.

\section{The Beach Armoring Index}

The physical qualities of beaches, such as beach width and profile and substrate composition, moisture, and temperature, influence the distribution of numerous VECs, such as eelgrass (Zostera marina), forage fish, and native shellfish (Dethier, 2006; Mumford, 2007; Penttila, 2007). Coastal bluff erosion is the primary source of beach sediment in Puget Sound, and this sediment source is essential for maintaining the quality of beaches and their associated habitats (Johannessen and MacLennan 2007).

A drift cell is a unit of coastline that represents a sediment transport sector from source to deposition. Drift cells have a net shore-drift direction, which is the long-term, net direction of longshore sediment transport. Within a drift cell, bulkheads or other shore armoring practices limit a bluff's erosion and reduce coastal sediment supply and transport to down-drift beaches, which results in changes to beach condition and habitat quality. Bluff-backed beaches and barrier beaches in Puget Sound appear to be the shoreforms most affected by armoring based on data in the Puget Sound change analysis geodatabase (Anchor QEA, 2009). Examples of Puget Sound bluff-backed beaches and barrier beaches are shown in figure 7. Common consequences of shoreline armoring are erosion of the beach profile, reduced shallow-water habitat, and substrate composition, temperature, and moisture changes, which can lead to, among other things, decreased forage-fish spawning, reduced shellfish production, and decreased eelgrass growth (Johannessen and MacLennan, 2007). 


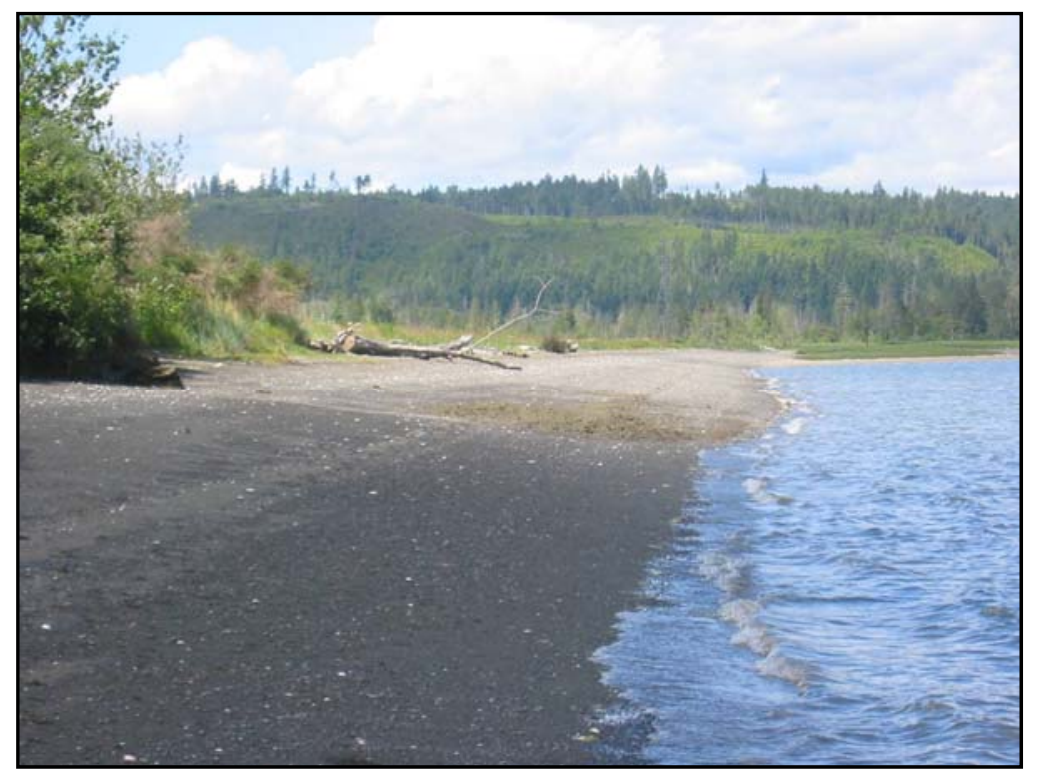

Figure 7. Photographs of examples of a bluff-backed beach and a barrier beach on Puget Sound, Washington. $A$, Barrier beaches are broad, flat beaches where sediment is deposited. $B$, Bluff-backed beaches form at the base of steep, eroding bluffs. (Photographs by Hugh Shipman, Washington Department of Ecology.)

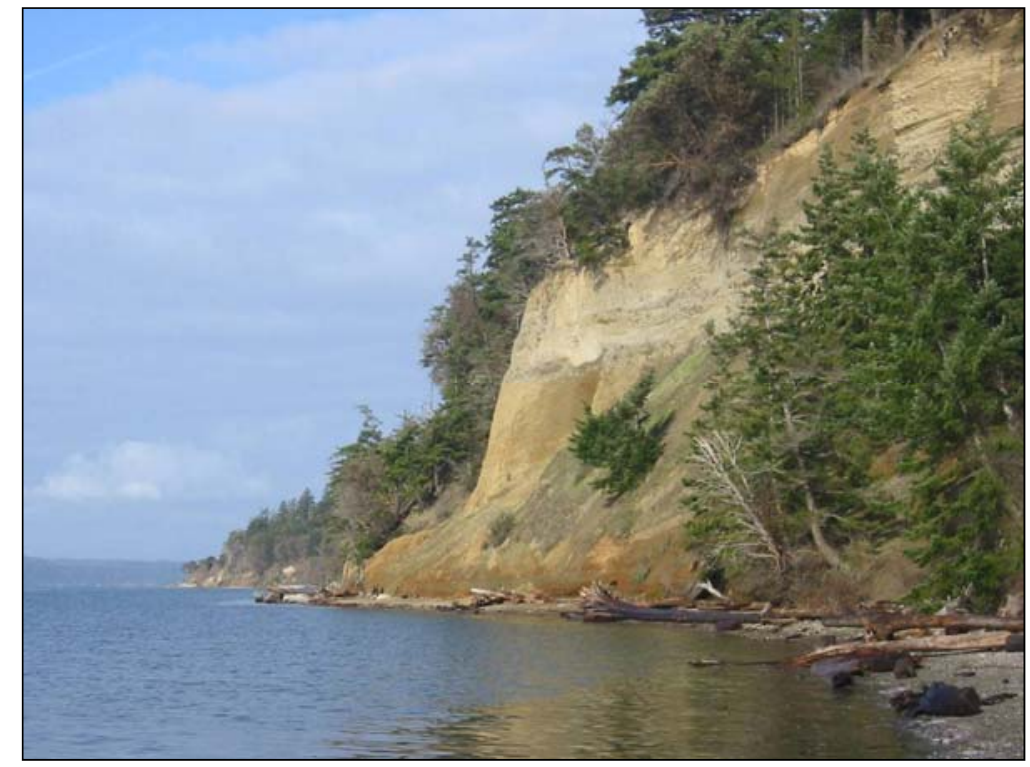

$B$

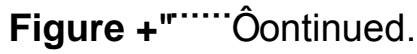

The Beach Armoring Index model provides a method for classifying Puget Sound beaches based on cumulative updrift and onsite armoring. Within a given drift cell, the index assigns each beach a score based on wave exposure and shoreline armoring onsite and updrift of coastal bluffs. The score indicates the potential for beach geomorphological and ecological changes resulting from loss of sediment supply. The index is used to compare ENVISION scenarios of future shoreline armoring to assess which shorelines are at greater risk of shoreline change and habitat loss. Although river 
deltas and streams also supply sediment to beaches, the index currently only addresses bluff sediment supply. Given these known limitations, we intend for the index to be a tool for evaluating armoring and development scenarios in Puget Sound into the future and not a deterministic predictor of shoreline change.

\section{Components of Index Development}

Indices based on the natural sciences should be relatively objective, transparent, and have the power to simplify scientific complexity (Goldberg, 2002). Development of an index includes several steps, including (1) selection of variables, (2) data transformation or standardization, (3) weighting, and (4) valuation (Goldberg, 2002). Just by selecting variables an implicit weighting is assigned to each variable, as the number of variables affects the relative importance of each one. Variable standardization is necessary when scales and (or) units of measure differ-each variable should show about the same order of magnitude. However, standardization may not be necessary if all variables are already percents or ratios (Booysen, 2002). Weighting is the process of judging the relative importance of each variable in an index. This can be done empirically; for example, through principle components analysis or by expert opinion (Rooney and Bayley, 2010).

Index scores are valued by comparing them to a predetermined classification of what constitutes high or low quality values. Correct classification criteria should be set $a$ priori or use of best professional judgment should justify the establishment of an $a$ posteriori scoring system (Borja and Dauer, 2008). It can be difficult to interpret the significance of index values, particularly in the absence of a benchmark such as a performance target (Goldberg, 2002).

As part of the valuation process, the index should be validated by testing it using an independent dataset, different than the index development dataset (calibration dataset) (Borja and Dauer, 2008). Indices may also be validated through the use of expert or best professional judgment. In general, index developers typically consider an index successful if it correctly differentiates 80 percent of sites having extreme or anomalous conditions, and use of expert judgment for validation has been found to achieve these results (Weisberg and others, 2008).

\section{Methods}

The aggregated Beach Armoring Index includes three variables:

1. Fetch distance measured from the South $\left(180^{\circ}\right)$ (SFetch),

2. Percent length of updrift bluffs that are armored (P_Up_Armor), and

3. Percent length of onsite bluffs that are armored ( $\mathrm{P}_{-}$Armor).

Fetch is the distance of open water that the wind can blow across without encountering any interfering landmass. Given winds of equal velocity and duration, the greater the fetch, the larger the wave that can be generated (Schwartz and others, 1989). Because of its topography and distribution of islands, wave energy in Puget Sound is fetch-limited. In the Beach Armoring Index, a fetch distance variable serves as an indicator of wave energy at a beach and a cross-shore erosion component to the model.

On the basis of findings in a dissertation by David Finlayson (2006), Puget Sound winds with speeds greater than 10 meters per second $(\mathrm{m} / \mathrm{s})$ - selected as a typical storm event - are primarily from the south (36 percent of the time). As strong storms are needed to mobilize coarse sediments on the beach, fetch distance measured from the south $\left(180^{\circ}\right)$ 
was selected as the fetch variable. Fetch distance was calculated for each bluff-backed and barrier beach using the fetch calculation program

(http://sites.google.com/site/davidpfinlayson/Home/programming/fetch, accessed September 8, 2011) (Finlayson, 2006), which is based on methods in the U.S. Army Corps of Engineers Shoreline Protection Manual (Coastal Engineering Research Center, 1984).

The extent of armored bluffs updrift and onsite of a beach serves as a measure of sediment supply loss to that beach. The model applies a network analysis method in GIS to attribute updrift and onsite armoring to a given bluff-backed or barrier beach in Puget Sound. To attribute cumulative updrift bluff armoring to a given beach, each drift cell in Puget Sound, as mapped in the Puget Sound change analysis geodatabase, was defined as a network with determinate flow in the net shore-drift direction. The geodatabase then provides source data for armoring and bluffs, which are defined as shoreforms=bluffbacked beaches (BLB). An“Upstream Accumulation" network analysis method calculates the percent length of updrift bluffs that are armored for each beach, as well as the percent length of onsite bluffs that are armored (fig. 8). ENVISION scenarios of shoreline armoring were then applied to calculate changes to these variables out to 2060 .

The index was calculated for all bluff-backed and barrier beaches that are not in zones of "No appreciable drift," as defined by the Puget Sound change analysis geodatabase. The three variables were assigned scores based on their data distribution. Scores were combined to create an index with values ranging 1 to 5 , with 5 being greatest potential for beach impacts. Based on consultation with USGS oceanographer Guy Gelfenbaum (oral commun., October 2009), the P_Up_Armor and SFetch variables were weighted double. This selection of weights served as an initial test of the relative importance of variables in the index. Variables were scored based on the data distributions displayed in table 3. 


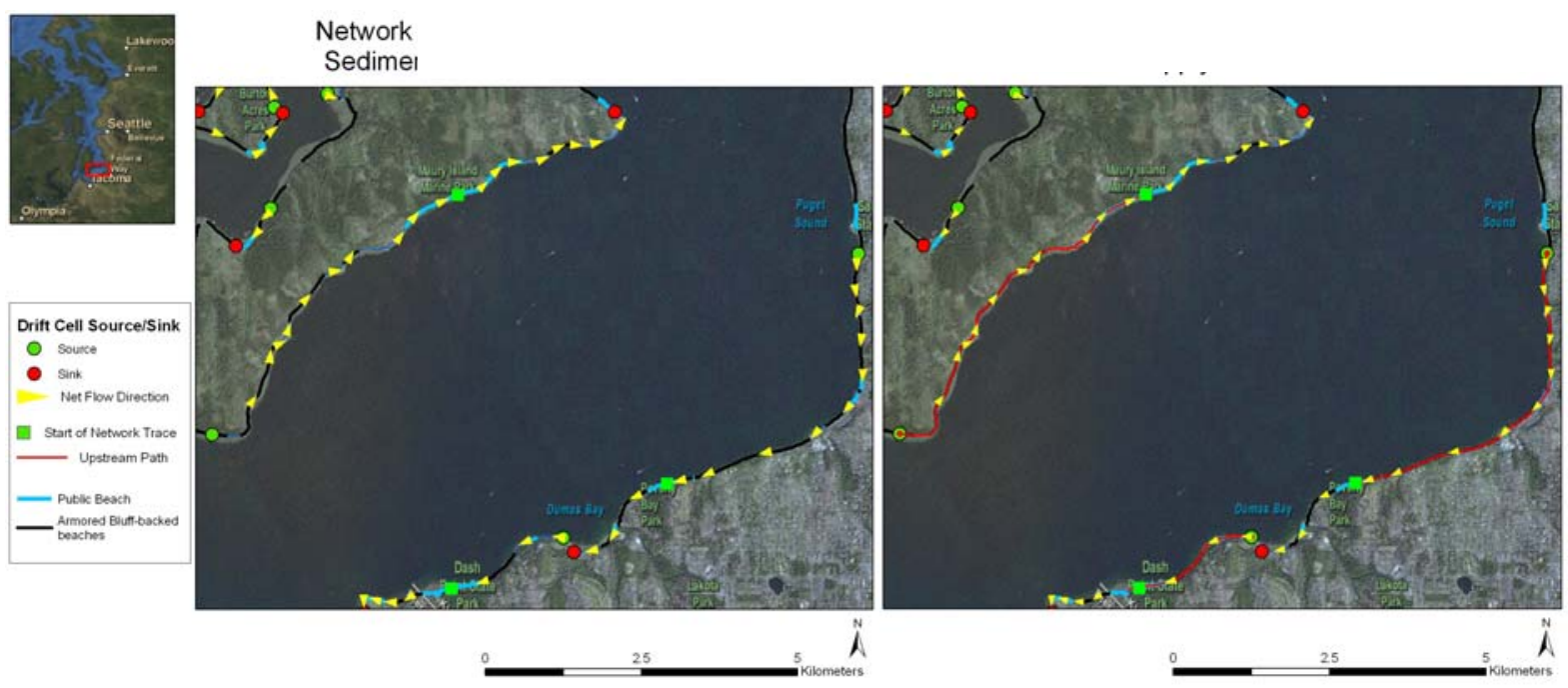

Figure 8. Cumulative effects analysis of Puget Sound, Washington, shoreline armoring using a geometric network in ArcGIS 9.3. In these figures, drift cells are represented as segments of shoreline, with the green points representing the starting point of the drift cell and the red points representing the end. In the figure on the left, a beach is assigned as the beginning of a network trace. Given the net flow direction of the drift cells (arrows), an "Upstream Accumulation" network analysis method calculates the length of armoring on all bluffs updrift of each beach, and assigns the cumulative armor length value to the beach record (as indicated by the red line along the shore).

Table 3. Beach Armoring Index variable scores, based on data distributions, used in the Puget Sound Ecosystem Portfolio Model.

[Variable scores are added to calculate a Beach Armoring Andex score for each beach in Puget Sound. P_Up_Armor $=$ percent length of updrift bluffs that are armored, SFetch $=$ fetch distance in meters measured from the south, and $\mathrm{P}_{\text {_ Armor }}=$ percent length of on-site bluff that is armored]

\begin{tabular}{ll}
\hline \multicolumn{1}{c}{ Data Range } & \multicolumn{1}{c}{ Score } \\
\hline P_Up_Armor & \\
\hline $0.1-25 \%$ & 0.25 \\
$25.1-50 \%$ & 0.50 \\
$50.1-75 \%$ & 0.75 \\
$>75 \%$ & 1.00 \\
\hline SFetch (m) & \\
\hline $0.1-2,500$ & 0.25 \\
$2,501-5,000$ & 0.50 \\
$5,001-7,500$ & 0.75 \\
$>7,500$ & 1.00 \\
\hline P_Armor & \\
\hline $0.1-50 \%$ & 0.25 \\
$50.1-90 \%$ & 0.5 \\
$>90 \%$ & 1.00 \\
\hline
\end{tabular}


The index is calculated as:

$2^{*}\left(P_{-}\right.$Up_Armor score $)+2^{*}($ SFetch score $)+\left[\left(P_{-}\right.\right.$Armor score $)$if Beach type $\left.=B L B\right]$

In this calculation, if the beach is a barrier beach, any armoring on that beach would not be counted in the index, given the assumption that armoring on a barrier beach has less impact on sediment supply than armoring on a bluff (most sediment is expected to come from bluffs).

Results

For the baseline year 2000 index score, south facing, armored shorelines scored higher than other shorelines. The southerly fetch distance is highly weighted in this index; changes to the fetch variable, such as the use of mean fetch, would greatly influence index calculations. There is also a trend toward higher index scores on the eastern shores of Puget Sound, from Possession Sound to Commencement Bay. The highest average index scores are in the South Central Subbasin (2.6) and the South Subbasin (2.1), which corresponds with higher armoring rates in these locations (table 4).

The ENVISION Managed Growth scenario assumed no future shoreline armoring; as a result, there is no change in index scores for this scenario across decades. For Status Quo and Unconstrained Growth scenarios, future shoreline armoring rates in the ENVISION model were based on current ratios between armoring density and shoreline development densities by zoning class, such as urban, suburban, or rural residential. The use of these ratios led to very low prediction rates for future shoreline armoring for both scenarios out to 2060. The greatest projected increase in armoring occurred in the 2060 Unconstrained Growth scenario for the South Central Puget Sound Subbasin - 4.6 percent increase in the length of armored shoreline (fig. 9).

A comparison of the 2060 Unconstrained Growth to Managed Growth scenarios finds an increase in index scores on parts of Bainbridge Island, parts of the South Puget Sound Subbasin, and parts of the Whidbey Subbasin.

Table 4. Average Beach Armoring Index score used in the Puget Sound Ecosystem Portfolio Model, by scenario, year, and subbasin.

[The highest average index scores are in the South Central Subbasin (2.6) and the South Subbasin (2.1), which corresponds with higher armoring rates in these locations]

\begin{tabular}{|c|c|c|c|c|c|c|c|c|}
\hline \multirow[b]{2}{*}{ Scenario } & \multicolumn{8}{|c|}{ Subbasin } \\
\hline & $\begin{array}{l}\text { Hood } \\
\text { canal }\end{array}$ & $\begin{array}{c}\text { Juan de } \\
\text { Fuca }\end{array}$ & $\begin{array}{l}\text { North } \\
\text { central }\end{array}$ & $\begin{array}{l}\text { South } \\
\text { central }\end{array}$ & $\begin{array}{l}\text { San } \\
\text { Juan }\end{array}$ & $\begin{array}{l}\text { South } \\
\text { Puget }\end{array}$ & Whidbey & $\begin{array}{l}\text { Puget } \\
\text { Sound }\end{array}$ \\
\hline \multicolumn{9}{|l|}{ Managed Growth } \\
\hline 2000 & 1.8 & 1.1 & 1.1 & 2.6 & 1.6 & 2.1 & 1.6 & 2.0 \\
\hline 2030 & 1.8 & 1.1 & 1.1 & 2.6 & 1.6 & 2.1 & 1.6 & 2.0 \\
\hline 2060 & 1.8 & 1.1 & 1.1 & 2.6 & 1.6 & 2.1 & 1.6 & 2.0 \\
\hline \multicolumn{9}{|l|}{ Status Quo } \\
\hline 2000 & 1.8 & 1.1 & 1.1 & 2.6 & 1.6 & 2.1 & 1.6 & 2.0 \\
\hline 2030 & 1.8 & 1.3 & 1.2 & 2.7 & 1.7 & 2.2 & 1.6 & 2.0 \\
\hline 2060 & 1.8 & 1.1 & 1.1 & 2.7 & 1.6 & 2.1 & 1.6 & 2.0 \\
\hline \multicolumn{9}{|c|}{ Unconstrained Growth } \\
\hline 2000 & 1.8 & 1.1 & 1.1 & 2.6 & 1.6 & 2.1 & 1.6 & 2.0 \\
\hline 2030 & 1.8 & 1.3 & 1.2 & 2.7 & 1.7 & 2.2 & 1.6 & 2.0 \\
\hline 2060 & 1.8 & 1.2 & 1.1 & 2.7 & 1.7 & 2.2 & 1.6 & 2.0 \\
\hline
\end{tabular}




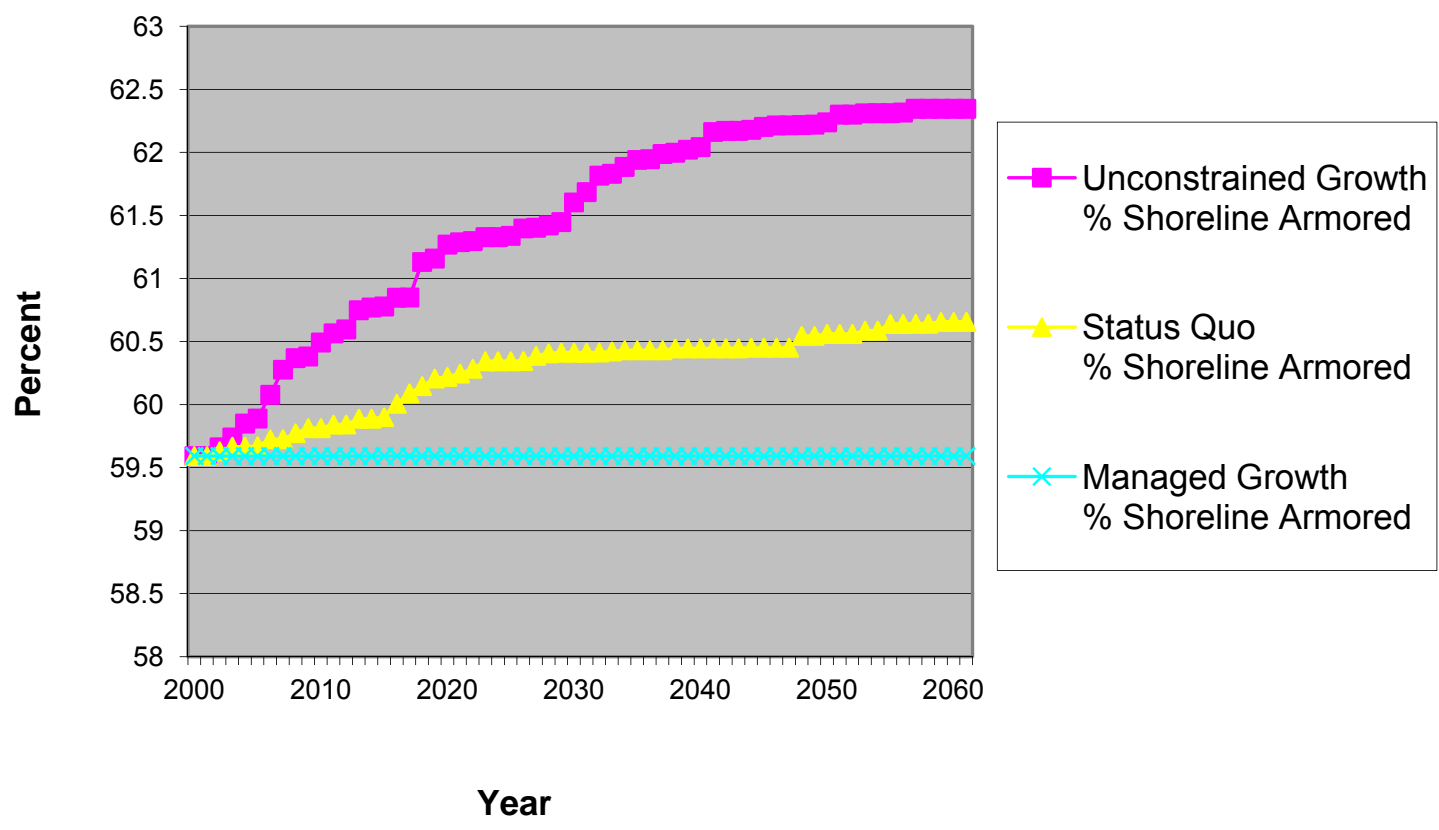

Figure 9. ENVISION armoring projections for the South Central Puget Sound Subbasin used in the Puget Sound Ecosystem Portfolio Model. The greatest projected increase in armoring occurred in the 2060 Unconstrained Growth scenario for the South Central Puget Sound Subbasin-a 4.6 percent increase in the length of armored shoreline.

\section{Focused Studies for Further Index Development}

Bainbridge Island Case Study

We conducted a study on Bainbridge Island to test Beach Armoring Index variations with variable selection and weights and to test a validation method. We selected Bainbridge Island because of its small size, transportation access, abundance of existing nearshore data, and prevalence of shoreline development and armoring (fig. 10). The case study had two components - (1) a sensitivity analysis of the index using different variables to represent fetch distance and feeder bluff sediment supply and (2) a pilot field validation using a rapid field assessment method. In the sensitivity analysis of the index, two fetch distance variables were tested - (1) fetch distance measured from the south $\left(180^{\circ}\right)$ to a given beach and (2) maximum value of six fetch distances ranging from southwest $\left(225^{\circ}\right)$ to southeast $\left(135^{\circ}\right)$. The relative weight of the fetch variable in the index was also tested. Two feeder bluff variables included (1) feeder bluff location and length as recorded in the PSNERP change analysis geodatabase and (2) feeder bluff locations as mapped by Coastal Geologic Services, Inc. (CGS) in 2010 (MacLennan and others, 2010). 


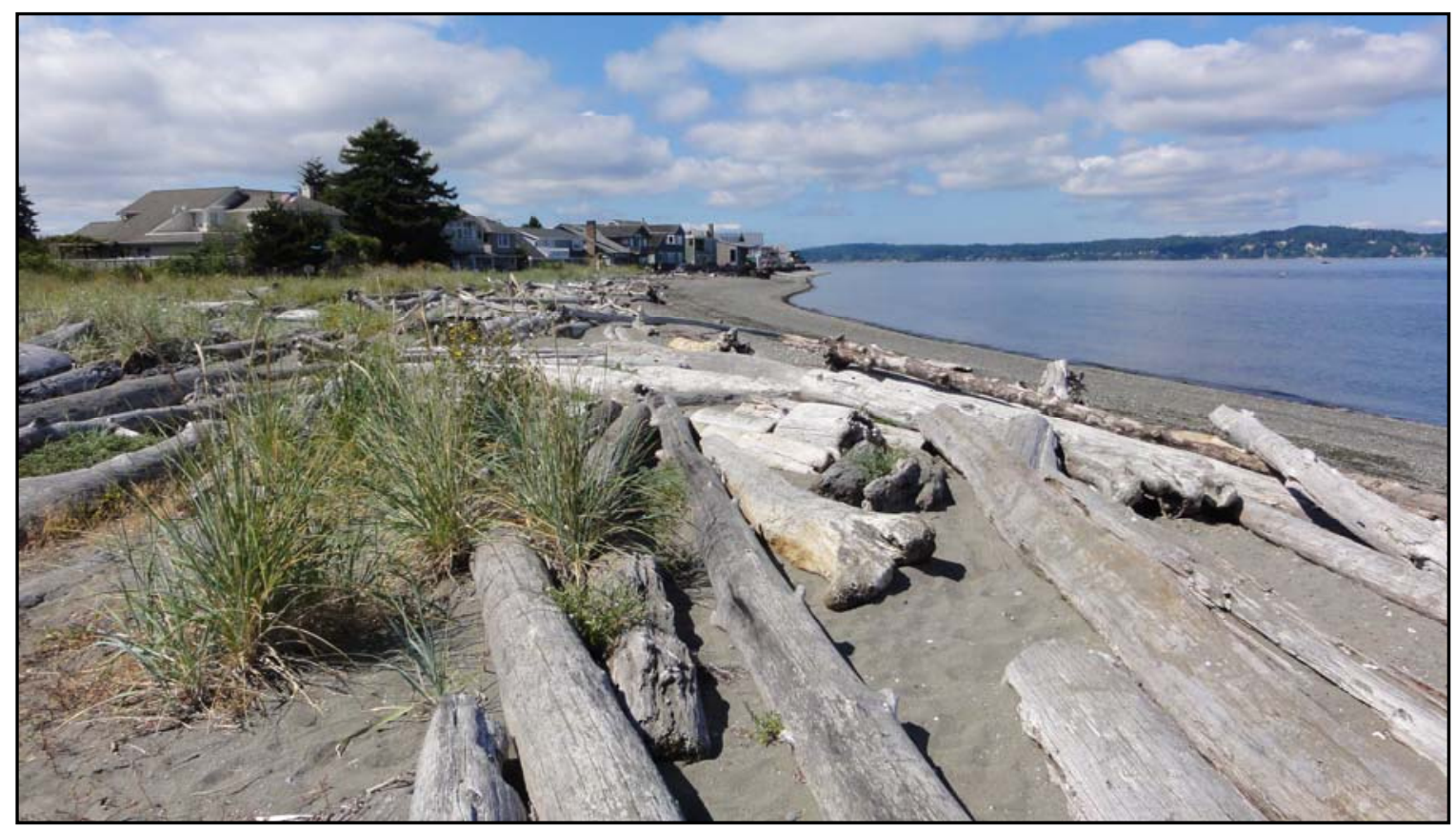

Figure 10. Photograph of Bainbridge Island, Washington. We conducted a case study on Bainbridge Island to test Beach Armoring Index variations with variable selection and weights and to test a validation method. Bainbridge Island was selected because of its small size, transportation access, abundance of existing nearshore data, and prevalence of shoreline development and armoring.

MacLennan and others (2010) mapped feeder bluffs on Bainbridge Island according to methods they developed for King County (Johannessen and others, 2005). The mapping process classifies current and historical (now armored) feeder bluffs as feeder bluff (FB) or feeder bluff exceptional (FBE). FBE classification was applied to bluff segments that were eroding rapidly and were characterized by the presence of recent landslide scarps and (or) bluff-toe erosion and abundant sand/gravel in the bluff, among other features. The FB classification was used for areas having past landslide scarps, intermittent toe erosion and moderate amounts of sand/gravel in the bluff, among other features. Shoreline segments that had been bulkheaded or otherwise modified such that the bank no longer provided sediment input to the beach system were labeled Modified. Historical feeder bluffs (presently modified shorelines) were classified using an index developed by Johannessen and others (2005), the Historic Sediment Source Index, which demanded investigation of shoreline reach topography, surface geology, known landslide history, landscape and net shore-drift context, historical topographic maps, and historical air photos. In addition, MacLennan and others (2010) created maps of the Bainbridge Island drift cells, including their net direction of longshore transport.

The feeder-bluff maps by MacLennan and others (2010) improved on the feederbluff data provided in the PSNERP change analysis geodatabase in that they provided more accurate locations and lengths of feeder bluffs and identified the relative contribution of sediment by each feeder bluff to the drift cell. To apply the feeder-bluff data in the Beach Armoring Index, a new network of drift cells was developed in ArcGIS using the drift-cell map by MacLennan and others (2010). The "Calculate Accumulation" 
script was applied to calculate for each beach, the percent length of updrift FBs that were armored, and the percent length of updrift FBEs that were armored.

Sensitivity Analysis

Overall, eight different indices were developed and compared. Because the total value of each index varied from 5 to 8 , index scores were standardized by converting the scores to a proportion of the total possible score so that indices could be compared. The eight indices are listed below in table 5, and table 6 provides variable definitions and shows how each variable score was calculated.

\section{Table 5. Eight variations of the Beach Armoring Index used in the Puget Sound Ecosystem Portfolio Model.}

[In this sensitivity analysis, two fetch distance variables were tested-(1) fetch distance measured from the south $\left(180^{\circ}\right)$ to a given beach (SFetch) and (2) maximum value of six fetch distances ranging from southwest $\left(225^{\circ}\right)$ to southeast $\left(135^{\circ}\right)$ (MaxFetch). The relative weight of the fetch variable in the index was also tested. Two feeder bluff variables included (1) feeder bluff location and length as recorded in the PSNERP change analysis geodatabase and (2) feeder bluff location and length as mapped by Coastal Geologic Services, Inc., (CGS) in 2010 (MacLennan and others, 2010). Variable definitions are provided below in table 6]

\begin{tabular}{|c|}
\hline Set 1-using PSNERP geodatabase feeder bluff data \\
\hline $2($ SFetch score $)+2\left(P_{-} U_{p} \_\right.$Armor score $)+\left[\left(P_{-}\right.\right.$Armor score $)$if beach type $=$BLB $\left.)\right]$ \\
\hline $2($ MaxFetch score $)+2\left(P_{-} \_\right.$Up_Armor score $)+\left[\left(P_{-}\right.\right.$Armor score $)$if beach type $=$BLB $\left.)\right]$ \\
\hline$($ SFetch score $)+2\left(P_{-}\right.$Up_Armor score $)+\left[\left(P_{-}\right.\right.$Armor score $)$if beach type $=$BLB $\left.)\right]$ \\
\hline$($ MaxFetch score $)+2\left(P_{-} \_\right.$Up_Armor score $)+\left[\left(P_{-}\right.\right.$Armor score $)$if beach type $=$BLB $\left.)\right]$ \\
\hline
\end{tabular}

Set 2-using CGS Feeder Bluff data

$2($ SFetch score $)+2\left(P_{\_}\right.$FBE_Armor score $)+2\left(P_{-}\right.$FB_Armor score $)+\left[\left(P_{-}\right.\right.$Armor score $)$if beach type $=$FB $)$ or $2\left(\mathrm{P} \_\right.$Armor score $)$if beach type $\left.\left.=\mathrm{FBE}\right)\right]$

$2($ MaxFetch score $)+2\left(\mathrm{P}_{\_}\right.$FBE_Armor score $)+\left(\mathrm{P} \_\right.$FB_Armor score $)+\left[\left(\mathrm{P}_{-}\right.\right.$Armor score $)$if beach type $=$ $\mathrm{FB})$ or 2(P_Armor score $)$ if beach type $=\mathrm{FBE})]$

$(\mathrm{SFetch}$ score $)+2\left(\mathrm{P}_{-}\right.$FBE_Armor score $)+\left(\mathrm{P}_{-}\right.$FB_Armor score $)+\left[\left(\mathrm{P}_{-}\right.\right.$Armor score $)$if beach type $\left.=\mathrm{FB}\right)$ or 2(P_Armor score $)$ if beach type $=\mathrm{FBE})]$

$($ MaxFetch score $)+2\left(P_{-}\right.$FBE_Armor score $)+\left(P_{-}\right.$FB_Armor score $)+\left[\left(P_{-}\right.\right.$Armor score $)$if beach type $=$ $\mathrm{FB})$ or 2(P_Armor score $)$ if beach type $=\mathrm{FBE})]$ 


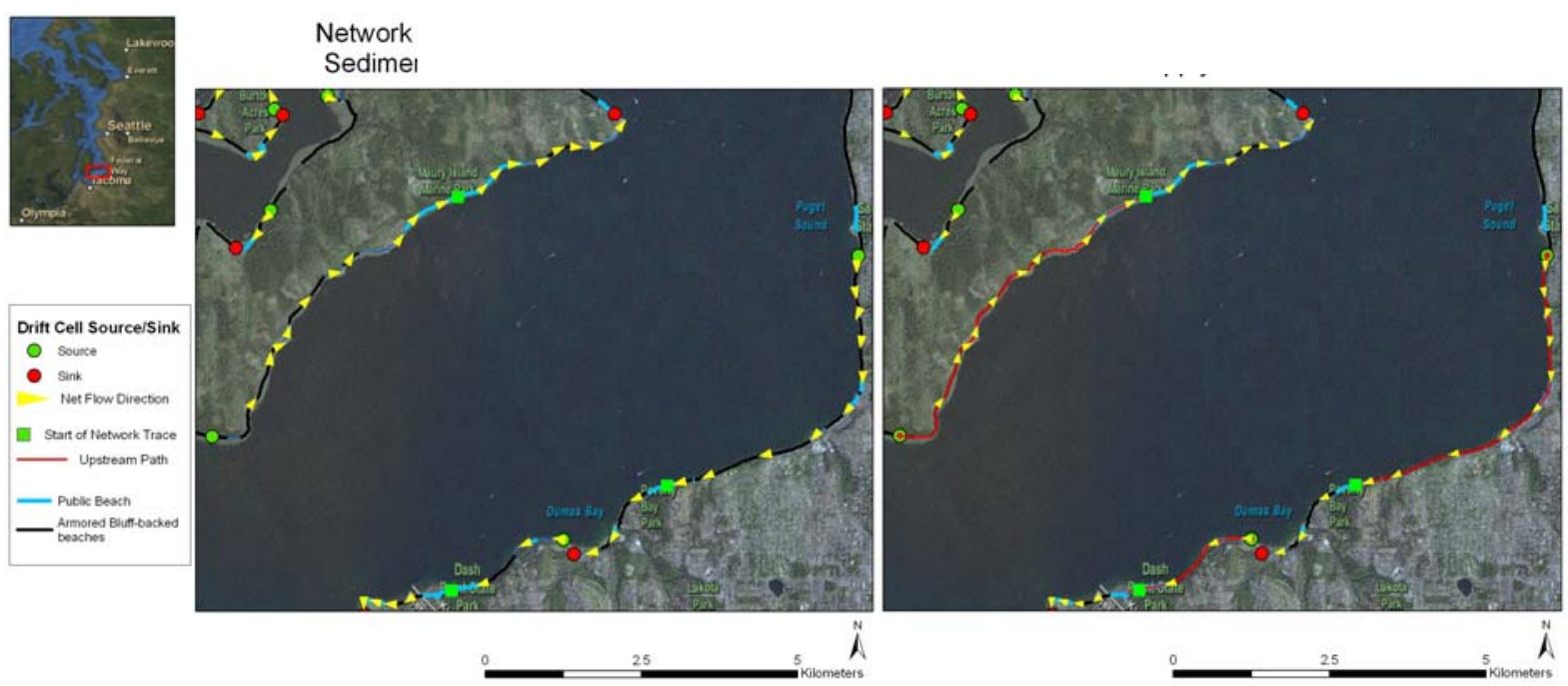

Figure 8. Cumulative effects analysis of Puget Sound, Washington, shoreline armoring using a geometric network in ArcGIS 9.3. In these figures, drift cells are represented as segments of shoreline, with the green points representing the starting point of the drift cell and the red points representing the end. In the figure on the left, a beach is assigned as the beginning of a network trace. Given the net flow direction of the drift cells (arrows), an "Upstream Accumulation" network analysis method calculates the length of armoring on all bluffs updrift of each beach, and assigns the cumulative armor length value to the beach record (as indicated by the red line along the shore).

Table 3. Beach Armoring Index variable scores, based on data distributions, used in the Puget Sound Ecosystem Portfolio Model.

[Variable scores are added to calculate a Beach Armoring Andex score for each beach in Puget Sound. P_Up_Armor $=$ percent length of updrift bluffs that are armored, SFetch $=$ fetch distance in meters measured from the south, and $\mathrm{P}_{-}$Armor $=$percent length of on-site bluff that is armored]

\begin{tabular}{ll}
\hline \multicolumn{1}{c}{ Data Range } & \multicolumn{1}{c}{ Score } \\
\hline P_Up_Armor & \\
\hline $0.1-25 \%$ & 0.25 \\
$25.1-50 \%$ & 0.50 \\
$50.1-75 \%$ & 0.75 \\
$>75 \%$ & 1.00 \\
\hline SFetch (m) & \\
\hline $0.1-2,500$ & 0.25 \\
$2,501-5,000$ & 0.50 \\
$5,001-7,500$ & 0.75 \\
$>7,500$ & 1.00 \\
\hline P_Armor & \\
\hline $0.1-50 \%$ & 0.25 \\
$50.1-90 \%$ & 0.5 \\
$>90 \%$ & 1.00 \\
\hline
\end{tabular}


functional response of a beach to changes in sediment supply specifically, we also tested subsets of the field assessment data for validation. Two subset datasets were generated and tested and included only those variables that were more likely to respond to changes in sediment supply or be an indicator of changes in sediment supply. Subset A included the metrics driftwood, eelgrass, and flats, and subset B included the metrics eelgrass and flats. These variables were selected as indicators because driftwood, or large woody debris, originates from eroding bluffs (Brennan and others, 2009) and eelgrass grows in muddy to sandy substrates on flats (Mumford, 2007), which are supplied by eroding bluffs (Johannessen and MacLennan, 2007).

Indicators for the flats metric included percent of shoreline unit with flats beyond 0 mean lower low water, average width of flats, and dominate substrate. Indicators for the driftwood metric included percent of shoreline unit with drift logs above 0 mean lower low water, average width of a patch of drift logs, composition of drift logs, and number of large woody debris pieces lying perpendicular to the shore. For the eelgrass metric, indicators included percent of shoreline unit with eelgrass in the intertidal zone, average width of eelgrass along the transect, eelgrass cover (patchy or continuous), and composition of eelgrass (eelgrass only or combined with macroalgae).

Using the technique described in Borde and others (2009), we standardized the scores from each site by converting the scores to represent a proportion of the total possible score. Functional assessment scores ranging from 0 to 0.2 were ranked low, scores ranging from 0.21 to 0.60 were ranked moderate, and scores ranging from 0.61 to 1 were ranked high, with breaks based on the highest possible score for each category. The Fay-Bainbridge site consistently received a high functional score for all sets of metrics including the full set and both subsets. Rockaway Beach received a moderate score for the complete metric set but a low score for the two subsets. Battle Point received a marginally high score for the complete metric set and moderate scores for the two subsets (table 7).

\section{Table 7. Field validation scores for the Beach Armoring Index based on a field assessment method developed by Borde and others (2009).}

[The complete metric set included flats, driftwood, vegetation, eelgrass, and wrack. Subset A included the metrics driftwood, eelgrass, and flats, and subset B included the metrics eelgrass and flats. The FayBainbridge site consistently received a high functional score for all sets of metrics including the full set and both subsets. Rockaway Beach received a moderate score for the complete metric set but a low score for the two subsets. Battle Point received a marginally high score for the complete metric set and moderate scores for the two subsets]

\begin{tabular}{llll}
\hline \multicolumn{1}{c}{ Score } & Fay-Bainbridge & \multicolumn{1}{c}{ Rockaway Beach } & \multicolumn{1}{c}{ Battle Point } \\
\hline $\begin{array}{l}\text { Complete metric set } \\
\text { Subset A: driftwood, eelgrass, }\end{array}$ & 0.71 (high) & 0.27 (moderate) & 0.61 (high) \\
and flats & 0.77 (high) & 0.11 (low) & 0.56 (moderate) \\
Subset B: eelgrass and flats & 0.86 (high) & 0.09 (low) & 0.53 (moderate) \\
\hline
\end{tabular}

Index Comparison

The performance of the eight variations of the Beach Armoring Index were evaluated using the field validation data. Given that only three sites were sampled, this evaluation only serves as a test of this method for validating the indices. However, because the three sites represent three functional classes (low, moderate, and high), they 
provide an initial opportunity to explore index performance. In the future, more field assessment data is needed to complete a statistically robust validation.

Index scores were calculated for each of the three sites, for all eight index variations. Each index was then tested through a simple regression analysis against two sets of field validation data: (1) subset A-driftwood, eelgrass and flats, and (2) subset $\mathrm{B}$ - eelgrass and flats. Given that higher index scores represented greater potential loss in sediment supply, it was expected that index scores would be inversely related to field validation scores. It was also expected that indices derived from the CGS feeder-bluff data (MacLennan and others, 2010) would perform better, given the greater accuracy of the dataset.

Based on this simple analysis of pilot data, it appears that index scores derived from PSNERP change analysis geodatabase data correlate well with field validation data based on $R^{2}$ values and explain more of the variation in the data (table 8 ). Index scores derived from the CGS feeder-bluff data are not as well correlated with the validation data as those derived from the PSNERP data, possibly because the aggregation and weighting of the CGS feeder-bluff index did not adequately distinguish sites based on functional characteristics. However, no significant conclusions can be drawn yet from this initial analysis. Instead this method represents a means to evaluate the indices once more field validation data is collected.

Table 8. Beach Armoring Index scores and correlation with field validation data used in the Puget Sound Ecosystem Portfolio Model.

[Index scores were calculated for each of the three sites, for all eight index variations. Each index was then tested through a simple regression analysis against two sets of field validation data: (1) subset Adriftwood, eelgrass and flats, and (2) subset B - eelgrass and flats. FB = CGS feeder bluff data (MacLennan and others, 2010); PS = PNSERP geodatabase data; Sfetch = Fetch distance measured from $180^{\circ}$; Max fetch $=$ Maximum fetch distance of 6 directions ranging from SE $\left(135^{\circ}\right)$ to $\mathrm{SW}\left(225^{\circ}\right)$ ]

\begin{tabular}{|c|c|c|c|c|c|}
\hline \multirow[b]{2}{*}{ Index } & \multicolumn{3}{|c|}{ Index Score } & \multicolumn{2}{|c|}{ Validation } \\
\hline & $\begin{array}{c}\text { Fay } \\
\text { Bainbridge }\end{array}$ & $\begin{array}{c}\text { Rockaway } \\
\text { Beach }\end{array}$ & Battle Point & $\begin{array}{l}R^{2} \text { Index: } \\
\text { subset A }\end{array}$ & $\begin{array}{l}R^{2} \text { Index: } \\
\text { subset } B\end{array}$ \\
\hline FB, 2xSfetch & 0.38 & 0.44 & 0.31 & 0.45 & 0.33 \\
\hline FB, $2 x M a x$ fetch & 0.56 & 0.63 & 0.31 & 0.15 & 0.08 \\
\hline FB, 1xSfetch & 0.39 & 0.46 & 0.32 & 0.45 & 0.33 \\
\hline FB, 1xMax fetch & 0.50 & 0.57 & 0.32 & 0.22 & 0.13 \\
\hline PS, 2xSfetch & 0.30 & 0.60 & 0.50 & 0.85 & 0.92 \\
\hline PS, 2xMax fetch & 0.60 & 0.90 & 0.50 & 0.72 & 0.61 \\
\hline PS, 1xSfetch & 0.31 & 0.69 & 0.56 & 0.85 & 0.92 \\
\hline PS, 1xMax fetch & 0.50 & 0.88 & 0.56 & 0.97 & 0.92 \\
\hline
\end{tabular}

Statistics-based Index Development

A second, statistics-based approach was explored for developing a Beach Armoring Index using ordered logistic regression. This approach uses a maximum likelihood method to estimate the probability that a beach score falls within an ordered response category. In this case, the independent variables are those that make up the aggregated indices described above. Independent variables tested in the regression analyses included SFetch, Maxfetch, P_Up_Armor, P_Armor, and P_Armor_Sum (the percent length of all bluffs onsite and updrift that are armored). The response variable 
was a category of beach ecological function, low, medium or high, as defined by the Controlling Factors Model rapid field assessment method (Borde and others, 2009).

Ten field validation sites in east Kitsap County, including Bainbridge Island, were selected for this analysis (fig. 11). These included seven beach sites that were scored in Borde and others (2009), and three sites on Bainbridge Island that we scored in August 2010. As in the Bainbridge Island case study, three sets of scores were calculated for each site-(1) The Controlling Factors Model complete metric set (flats, driftwood, vegetation, eelgrass, and wrack), (2) metric subset A (driftwood, flats, and eelgrass), and (3) metric subset B (mudflats and eelgrass).

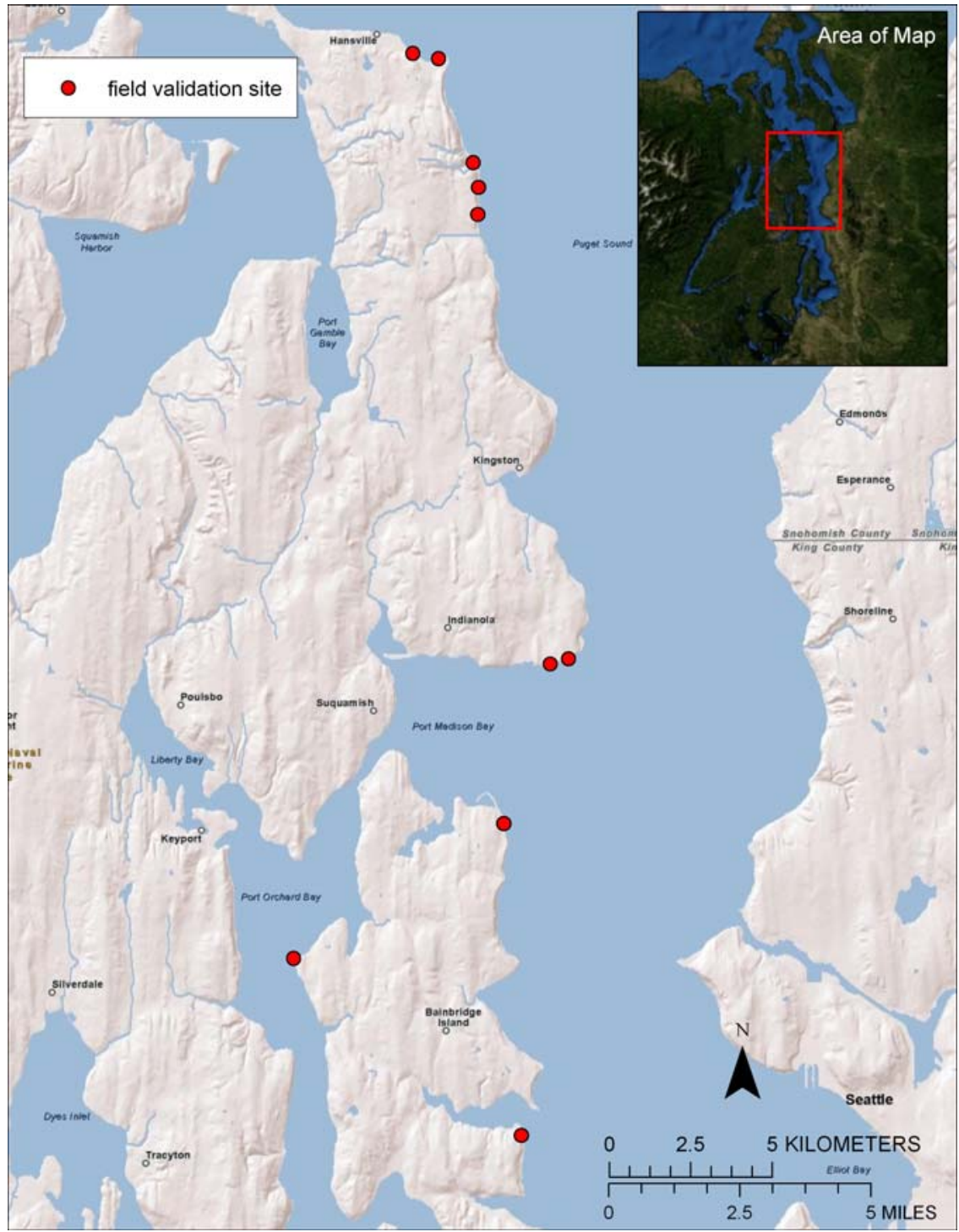

Figure 11. Map showing 10 field validation sites in east Kitsap County, Washington, including Bainbridge Island, used for statistics-based development of the Beach Armoring Index. Field validation sites are shown in red.

Multiple regression models were tested using combinations of different fetch and armoring variables. Variables with high collinearity were not included together in 
models. Model accuracy was assessed by assigning "classification accuracy" cases to fitted probabilities of 0.6 or greater.

The best model using the complete metric set included the variables $\mathrm{P}_{-}$Armor, Sfetch, and P_Up_Armor. This model was significant $\left(P>\mathrm{chi}^{2}=0.036, \mathrm{n}=10\right)$ with a pseudo $R^{2}$ of 0.45 , which represents the proportion of variation explained by the model. For metric subset B (eelgrass and flats), the best model also included variables $\mathrm{P}$ Armor, Sfetch, and P_Up_Armor $\left(P>\operatorname{chi}^{2}=0.052, n=10\right)$. The pseudo $R^{2}$ was 0.37 (table 9$)$. The model using metric subset A was not significantly different from the model using metric subset B, so model A results were not reported. In both cases, 7 out of 10 sites were classified accurately, so the classification accuracy was 70 percent for both metrics (table $10)$.

Table 9. Ordered logistic regression results for the full model set and metric subset B.

[A maximum likelihood statistical method was used to estimate the probability that a field assessment beach score can be explained by variables in the Beach Armoring Index. Significant variables in final statistical models included: $\mathrm{P}$ Armor (percent length of on-site bluff that is armored), Sfetch (fetch distance in meters measured from $180^{\circ}$ ), and P_Up_Armor (percent length of bluffs updrift of beach that are armored)]

\begin{tabular}{|c|c|c|c|c|c|c|}
\hline Variable & Coefficient & $\begin{array}{l}\text { Standard } \\
\text { error }\end{array}$ & $\mathbf{Z}$ & $P>Z$ & \multicolumn{2}{|c|}{$\begin{array}{l}95 \% \text { confidence } \\
\text { interval }\end{array}$} \\
\hline \multicolumn{7}{|c|}{$\begin{array}{l}\text { Complete model set: number of observations }=10, \mathrm{LR} \mathrm{chi}^{2}=8.57, \text { probability }>\mathrm{chi}^{2}=0.0356 \text {, } \\
\log \text { likelihood }=-5.1494049, \text { pseudo } R^{2}=0.4541\end{array}$} \\
\hline P_Armor & -7.0152 & 4.4484 & -1.5800 & 0.1150 & -15.7339 & 1.7034 \\
\hline Sfetch & -0.0003 & 0.0002 & -1.4400 & 0.1500 & -0.0008 & 0.0001 \\
\hline P_Up_Armor & 5.0122 & 3.6210 & 1.3800 & 0.1660 & -2.0848 & 12.1092 \\
\hline \multicolumn{7}{|c|}{$\begin{array}{l}\text { Metric subset B: number of observations }=10, \mathrm{LR}_{\mathrm{chi}}{ }^{2}=7.70, \text { probability }>\mathrm{chi}^{2}=0.0525 \text {, } \\
\log \text { likelihood }=-6.444367 \text {, pseudo } R^{2}=0.3741\end{array}$} \\
\hline P_Armor & -8.4464 & 4.4762 & -1.8900 & 0.0590 & -17.2196 & 0.3269 \\
\hline Sfetch & -0.0002 & 0.0001 & -1.6600 & 0.0960 & -0.0004 & 0.0000 \\
\hline P Up Armor & 1.9950 & 2.8437 & 0.7000 & 0.4830 & -3.5786 & 7.5686 \\
\hline
\end{tabular}


Table 10. Classification accuracy of scores from the complete model set and metric subset $B$ based on ordered logistic regression results.

[Green values represent sites that were accurately classified and red values represent sites that were not accurately classified]

\begin{tabular}{llll}
\hline \multicolumn{1}{c}{ Score } & Low & Medium & High \\
\hline Full set & & & \\
\hline 2 & 0.00 & 0.64 & 0.36 \\
3 & 0.00 & 0.06 & 0.94 \\
2 & 0.07 & 0.90 & 0.03 \\
1 & 0.92 & 0.08 & 0.00 \\
3 & 0.00 & 0.30 & 0.70 \\
3 & 0.00 & 0.30 & 0.69 \\
3 & 0.01 & 0.80 & 0.20 \\
2 & 0.00 & 0.38 & 0.62 \\
2 & 0.00 & 0.38 & 0.61 \\
3 & 0.00 & 0.16 & 0.84 \\
\hline Subset B & & & \\
\hline 1 & 0.71 & 0.27 & 0.02 \\
3 & 0.01 & 0.12 & 0.87 \\
2 & 0.19 & 0.63 & 0.18 \\
1 & 0.90 & 0.09 & 0.01 \\
2 & 0.02 & 0.29 & 0.69 \\
3 & 0.02 & 0.23 & 0.75 \\
3 & 0.21 & 0.63 & 0.16 \\
2 & 0.02 & 0.24 & 0.74 \\
3 & 0.02 & 0.24 & 0.74 \\
3 & 0.02 & 0.27 & 0.72 \\
\hline & & &
\end{tabular}

Using the regression equation developed with the complete metric set, rank scores were predicted for all beaches on Bainbridge Island. The map of these predicted results can be used to test the plausibility of this method for ranking beaches based on impacts from armoring (fig. 12). For example the map could be analyzed by experts in a workshop setting who evaluate the ranking system and provide suggestions for improvement. 


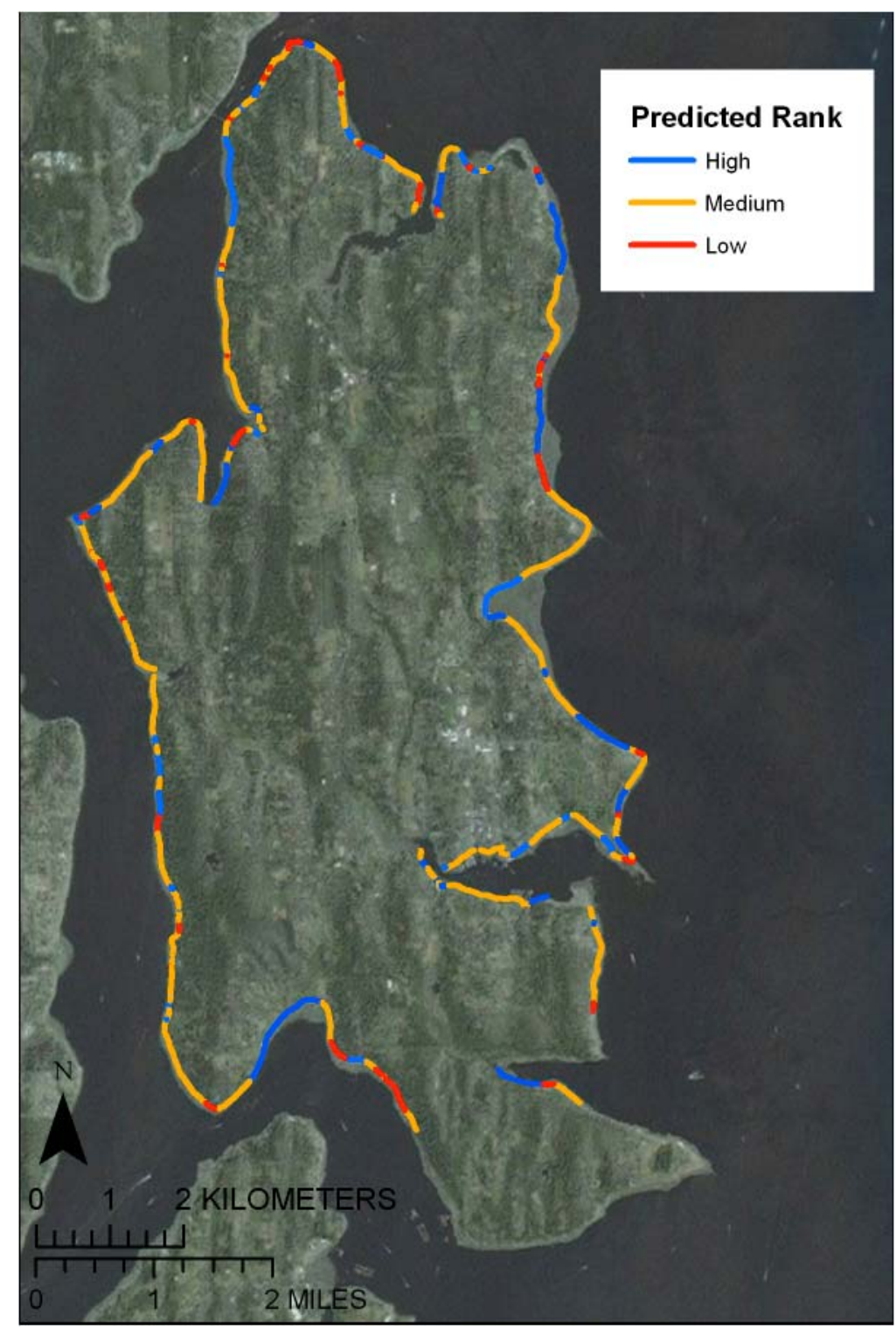

Figure 12. Map of Bainbridge Island predicted ordered logistic regression predictions based on full model set beach scores.

\section{Suggestions for Future Research}

The current Beach Armoring Index provides an analysis framework for classifying beaches based on cumulative armoring and fetch distance, yet more work is required to improve the model. In Puget Sound longshore sediment transport is an important process controlling beach morphology and supported habitats (Johannessen and MacLennan, 2007). One significant improvement to the Beach Armoring Index would be to add a component that represents the rate of sediment transport from feeder bluffs to beaches. However, few net shore-drift rate calculations have been made in the Puget Sound region (Wallace, 1988). As a proxy to using a complete longshore sediment transport model, significant variables in the model, such as wave height and wave angle, could be included as variables in the aggregated index or a statistics-based index. These variables could be modeled in SWAN (Simulating WAves Nearshore), a spectral wave 
model developed at the Delft University of Technology, The Netherlands (http://www.wldelft.nl/soft/swan/, accessed October 18, 2011). Scenarios should also be improved to better predict shoreline armoring rates, incorporate sea level rise, and incorporate human adaptation strategies to sea level rise.

\section{The Recreational Visitation Model}

The Recreation Visitation Model evaluates changes in Washington State Parks visitation based on alternative future growth scenarios in the Puget Sound region. Recreational opportunities are a major contributor to human well-being in Puget Sound (Stinchfield and others, 2009; Guerry and others, 2011). Changes in land use and population growth will likely alter the recreational use of the nearshore environment, yet the changes in recreational use are unknown and will likely depend on the composition and configuration of future urban growth. Increased population and land-use change may stress recreation resources, but allow more people access, effectively increasing net visitation. To understand these dynamics we modeled current recreational use of coastal State parks in Puget Sound (fig. 17) using a dataset of mean monthly park attendance from 2001 to 2008. We then used our model and the ENVISION land-use scenarios to estimate the likely future recreational use, and the differences in recreational use among scenarios, to understand how the form of urban growth may affect human use of the nearshore environment through recreational visits.

\section{Methods}

We modeled recreational visitation as a function of park characteristics, population availability, and travel costs and access. The full set of variables describing park characteristics included park area, beach length, annual and summer precipitation, number of concessions, number of activities, shellfishing opportunities, and number of campsites (table 11).

Travel Distance and Demand

Recreational visitation rates are often a function of demand from nearby population centers, with demand typically declining with distance (Bateman and others, 1999; Brainard and others, 2001). We used an independent dataset from the Washington State Parks reservation system containing travelers' zip code origins to calculate a travel distance for each visit and then derive a distance decay relationship for visits to Puget Sound. This dataset allows for the creation of a general demand function for visits within 500 miles from origins to Puget Sound parks. Using a road and ferry system dataset and the Network Analyst toolbox in ArcGIS, travel distances were calculated for the entire origin/destination matrix. We then used this function to aggregate population within the travel distance around each park according to the empirical relationship, using the population availability (PA) method of Coombes and others (2009):

$$
P A=\sum_{i=1}^{n}\left[P_{i}\left(a \exp \left(-b x_{i}\right)\right)\right],
$$

where $n$ is the number of U.S. Census blocks or Canadian census divisions within the travel distance, $i$ is the census unit, $P$ is the population size of $i, a$ is a constant, $b$ is the decay coefficient, and $x$ is distance. 
Table 11. Summary statistics for all Recreational Visitation Model data from 57 Washington State parks.

[Recreational visitation was modeled as a function of park characteristics, population availability, and travel costs and access. Std. dev. = standard deviation; $\mathrm{ppt}=$ precipitation; $\mathrm{mm}=$ millimeters; $\mathrm{PWC}=$ personal watercraft, eq $1=$ equation 1]

\begin{tabular}{|c|c|c|c|}
\hline Variable & Unit & Mean & $\begin{array}{l}\text { Std. } \\
\text { dev. }\end{array}$ \\
\hline Annual Visits & Number of visitor days/year & 32,583 & 42,862 \\
\hline Campsites & Number & 38.80 & 47.40 \\
\hline Camping & Dummy & 0.75 & 0.43 \\
\hline Park size & Acres & 284.80 & 801.00 \\
\hline Shore length & Kilometers & 2,414 & 3,241 \\
\hline $\begin{array}{l}\text { Population } \\
\text { availability }\end{array}$ & Number of people (eq 1) & 29,214 & 33,422 \\
\hline Travel time $^{1}$ & Minutes & 128.90 & 62.60 \\
\hline Travel distance ${ }^{1}$ & Kilometers & 75.80 & 35.30 \\
\hline Ferry & Dummy & 0.31 & 0.46 \\
\hline PWC access & Dummy & 0.26 & 0.44 \\
\hline Activities & Number & 5.90 & 3.20 \\
\hline Concessions & Kilometers & 0.73 & 1.18 \\
\hline Annual ppt & $\mathrm{mm}$ & 925.70 & 335.10 \\
\hline Summer ppt & $\mathrm{mm}$ & 89.80 & 12.40 \\
\hline Sandy & Dummy & 0.31 & 0.46 \\
\hline Heritage & Dummy & 0.10 & 0.30 \\
\hline Shellfishing & Dummy & 0.82 & 0.38 \\
\hline
\end{tabular}

Travel Cost Methods

Recreational demand models typically use the travel cost method (TCM) to explain variation in visitation counts (Clawson, 1959; Knetsch, 1963; Parsons, 2003). These models assume that the visitation rate to a location is dependent on the travel costs from an origin to the destination, socioeconomic factors, and minimal entrance fees. With lower costs it is assumed that the visitation rate would increase or that any given user would make a greater number of trips. We modeled recreational visitation as a function of park characteristics, travel cost and access, and recreational demand. Our visitation dataset comes from Washington State Parks, which records visitation numbers through entrance, camping, and mooring fees. Data are available by month beginning in the late 1980s to mid-1990s to the present, dependent on park. Visits are a count variable modeled using the negative binomial distribution (Hilbe, 2008). The data are over dispersed (variance larger than the mean) and without zero counts; thus, two models were tested once specified - the negative binomial (NB) and the zero-truncated negative binomial (ZTNB) model. This technique addresses the three main problems associated with truncated count data - that counts are nonnegative integers, that counts cannot have zero values, and that the data are often over dispersed (Englin and Shonkwiler, 1995). We chose the most parsimonious model specification by minimizing AIC (Akaike 
information criterion) through an information theoretic approach (Burnam and Anderson, 1998), and estimated the models in Stata 11 (StataCorp, 2009).

The models for mean annual park visitation are estimated as:

$$
\ln V_{i}=\beta_{0}+C_{i} \beta_{1}+P_{i} \beta_{2}+D_{i} \beta_{3},
$$

where $V$ is the mean annual count of visitors at park $i, C$ is a vector for the park's travel cost and access, $P$ is a vector of characteristics of each park, and $D$ is the population availability surrounding each park.

\section{Results}

We found a significant trend that relates the visitation rate (number of visits/zip code population) to the distance traveled $\left(p<0.001, R^{2}=0.67\right.$, fig. 13) using the State park origin/destination data. This result was then entered into our models as the population availability variable to help explain the variation in State park visitation.

Results from our model are shown in table 12. Using the 57 State parks in the dataset and an information theoretic approach, we constructed a final model that retains five of the independent variables. The two specifications, NB and ZTNB, performed almost identically, with only small differences among coefficients and between chi ${ }^{2}$ statistics. We can therefore rule out a potential effect of the truncated nature of our data affecting the explanation of the heterogeneity in visitation rate. The variables that increased visitation include the park size and the number of possible activities at the park. Variables that negatively affected visitation include a dummy describing accessibility only through personal watercraft, the weighted population from the relationship in figure 14, and the travel time to a park from downtown Seattle. This model was used to forecast future recreation at each State park by using the projected population of the ENVISION future scenarios to add population and change the weighted population variable in our model. Differences among scenarios (Status Quo, Managed Growth, and Unconstrained Growth) were compared for the years 2000, 2030, and 2060. 
Table 12. Results from the Recreational Visitation Model (negative binomial (NB) and zerotruncated negative binomial models ) component of the Puget Sound Ecosystem Portfolio model.

[The variables that increased visitation include park size and the number of possible activities at the park. Variables that negatively affected visitation include a dummy variable describing accessibility only through personal watercraft, the weighted population (figure 13), and the travel time to a park from downtown Seattle. $\ln =$ natural $\log , \mathrm{PWC}=$ personal watercraft $\mathrm{PA}=$ population availability, $\mathrm{z}=\mathrm{z}$ test statistic, $\mathrm{p}=$ probability, $\mathrm{LR}=$ likelihood ratio]

\begin{tabular}{|c|c|c|c|c|c|c|c|c|}
\hline \multirow[b]{2}{*}{ Variable } & \multicolumn{4}{|c|}{ NB model } & \multicolumn{4}{|c|}{$\begin{array}{c}\text { Zero- } \\
\text { truncated } \\
\text { NB model }\end{array}$} \\
\hline & Coefficient & $\begin{array}{l}\text { Standard } \\
\text { error }\end{array}$ & $z$ & $p$ & Coefficient & $\begin{array}{l}\text { Standard } \\
\text { error }\end{array}$ & $z$ & $p$ \\
\hline campsites & 0.0078 & 0.0028 & 2.75 & 0.006 & 0.0078 & 0.0028 & 2.75 & 0.006 \\
\hline $\ln$ (acres) & 0.2232 & 0.0717 & 3.11 & 0.002 & 0.2232 & 0.0717 & 3.11 & 0.002 \\
\hline activities (\#) & 0.1332 & 0.0450 & 2.96 & 0.003 & 0.1332 & 0.0450 & 2.96 & 0.003 \\
\hline $\begin{array}{l}\text { PWC access } \\
\text { (dummy) }\end{array}$ & -1.6565 & 0.3036 & -5.46 & 0.000 & -1.6565 & 0.3036 & -5.46 & 0.000 \\
\hline $\ln (\mathrm{PA})$ & -0.4482 & 0.1420 & -3.16 & 0.002 & -0.4482 & 0.1420 & -3.16 & 0.002 \\
\hline $\begin{array}{l}\ln (\text { travel } \\
\text { time) }\end{array}$ & -0.9147 & 0.3174 & -2.88 & 0.004 & -0.9147 & 0.3174 & -2.88 & 0.004 \\
\hline $\begin{array}{l}\text { cons } \\
\text { Dependent } \\
\text { variable= } \\
\text { mean } \\
\text { annual park } \\
\text { visitation }\end{array}$ & $n=57$, LR c & ${ }^{2}=75.28, \mathrm{pr}$ & 6.24 & 0.000 & $n=57, \mathrm{LR}$ & 2.6794 & 6.24 & 0.000 \\
\hline
\end{tabular}




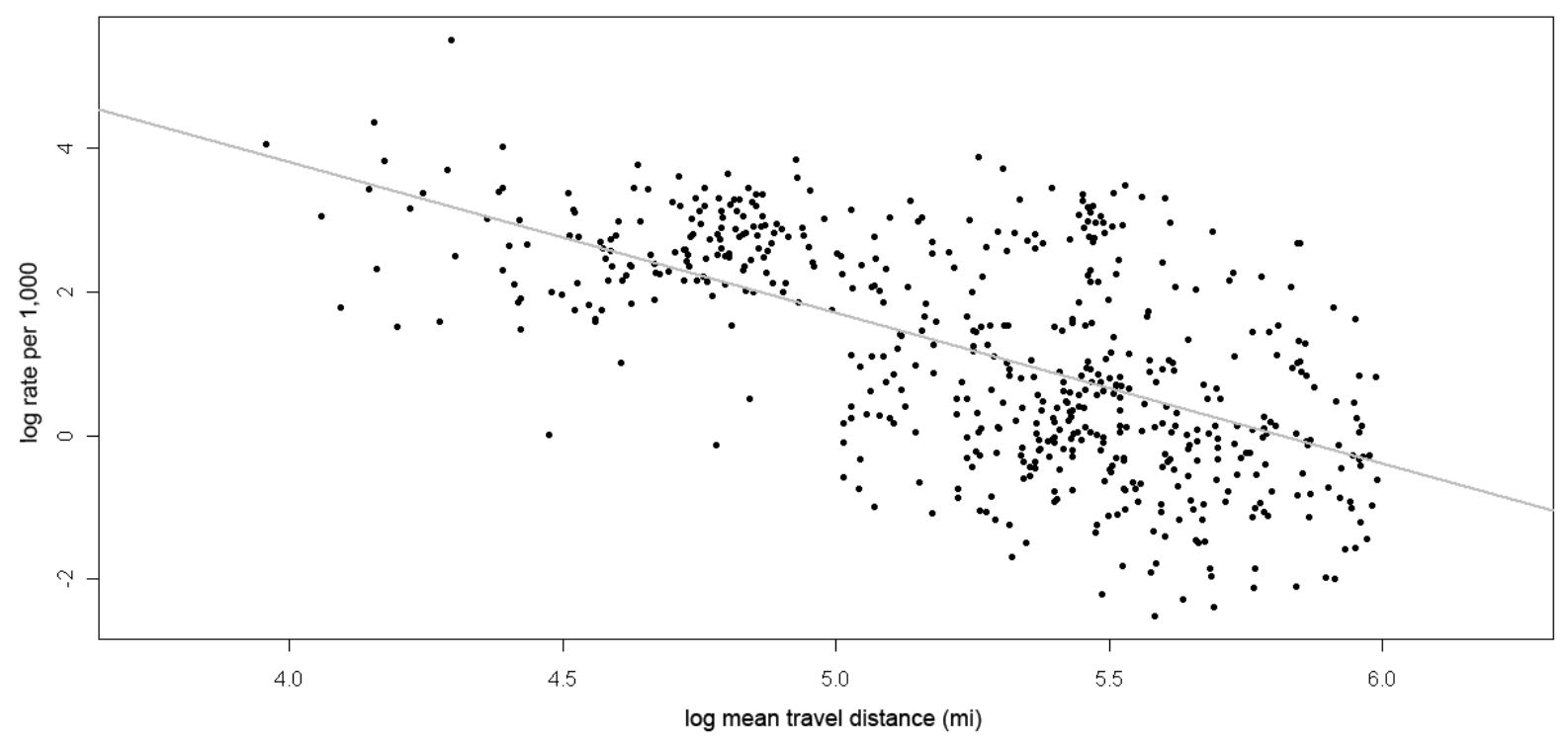

Figure 13. Demand function relating the visitation rate (number of visits per 1,000 individuals in population) to mean travel distance from zip code origins to Washington State parks within Puget Sound. Visitation rate (number of visits/zip code population) was significantly related to the distance traveled $(p<0.001, R 2=0.67)$ based on the State park origin/destination data. This result was then entered into the negative binomial model as the population availability variable to help explain the variation in State park visitation.

\section{Suggestions for Future Research}

When viewed through the ecosystem service lens-where opportunity for recreation is a ecosystem service in itself (Millennium Ecosystem Assessment, 2005; Chan and others, 2006) - visitation is the measure used to model and quantify this ecosystem service. Globally, trends in tourism related to outdoor recreation and wildlife viewing are increasing (Balmford and others, 2009). Recognition that ecosystem services play an important role in generating revenue for conservation and local development is also increasing (Gossling, 1999). We used the visitation rate model to understand the factors affecting the regional pattern of recreational visitation. Future application of this research could aid in guiding the restoration and water-quality improvement actions in Puget Sound to maximize the benefit to human well-being. To do so most effectively and efficiently, the full suite of ecosystem service benefits would be required before restoration planning or water-quality improvement actions can begin in earnest.

\section{Model Synthesis to Evaluate Potential Impacts to Valued Ecosystem Components and Ecosystem Services}

Two models - the Shellfish Pollution Model and the Beach Armoring Indexdescribe potential changes to beach condition - water quality and geomorphology and habitat. Results from these models and the Recreational Visitation Model influence potential changes to nearshore resources, including ecosystem goods and services and valued ecosystem components. Intersecting model results and existing data illustrates potential effects on nearshore resources across three scenarios out to 2060. These 
analyses explore potential changes to three resources - forage-fish spawning habitat, recreational shellfish beaches, and recreational beach quality.

\section{Forage-fish Spawning Habitat-An Intersection of Beach Armoring Index Scores at Forage- fish Spawning Beaches}

Forage fish, including surf smelt (Hypomesus pretiosus), Pacific sand lance (Ammodytes hexapterus), and Pacific herring (Clupea pallasi), are critical prey species for economically important predators such as salmon (Oncorhynchus spp.). These fish and their spawning habitats occur within the nearshore zone of Puget Sound beaches. To spawn, surf smelt and Pacific sand lance require a suitable amount of sand-gravel mix substrate at a tidal elevation in the uppermost one third of a shoreline's tidal range (Penttila, 2007). Shoreline armoring may be the primary threat to surf smelt and sand lance spawning habitat (Thom and others, 1994), as armoring results in physical burial of the upper intertidal zone and reduced sediment supply to beaches (Johannessen and MacLennan, 2007).

In October 2009, the Washington Department of Fish and Wildlife (WDFW) provided surf smelt and Pacific sand lance spawning occurrence data attributed to the Washington Department of Natural Resources ShoreZone GIS data (http://www.dnr.wa.gov/researchscience/topics/aquatichabitats/pages/aqr_nrsh_inventor y_projects.aspx, accessed October 18, 2011). Over the past 30 years, more than 30,000 samples were collected and mapped onto ShoreZone beaches. In the dataset, the number of surveys represents the number of times egg surveys were made at a given beach. A beach is designated a "spawning beach" if more than one egg is identified in one or more surveys. The WDFW Priority Habitats/Species Program forage-fish databases are considered "best available science," and the Washington State Growth Management Act urges local jurisdictions, including towns, cities, and counties, to adopt the use of the databases (Penttila, 2007).

For the Forage-fish Resource Impacts analysis, we intersected the WDFW database of surf smelt and Pacific sand lance spawning beaches with the Beach Armoring Index. Although multiple human stressors can threaten spawning beaches, including loss of marine riparian vegetation, the presence of overwater structures, and dredging (Penttila, 2007), our analysis focuses on threats from armoring, primarily the loss of beach sediment supply. As described in the Beach Armoring Index section, the ENVISION Managed Growth scenario assumed no future shoreline armoring; as a result, there is no change in index scores for this scenario across decades. Also, the ENVISION model projected low armoring rates in the Status Quo and Unconstrained Growth scenarios out to 2060; as a result, there are few changes in index scores for these beaches over time.

Overall, most forage-fish spawning beaches had moderate to low Beach Armoring Index scores ( 0.5 to 3 ). Only 159 beaches out of 1,091 had scores of 3.25 to 5 for the year 2000 baseline dataset. Most of these beaches were in the South Puget Sound Subbasin (73 beaches) (fig. 15) followed by the South Central Subbasin (54 beaches). As the ENVISION model projected minimal increases in beach armoring by 2060 for both the Unconstrained Growth and Status Quo scenarios, few forage-fish spawning beaches experience changes in index scores in the scenario analysis. Under the Unconstrained Growth scenario, the South Central Subbasin would experience the greatest increase in 
Beach Armoring Index scores by 2060, with 11 beaches changing, followed by the South Puget Subbasin, with 8 beaches changing (fig. 16).

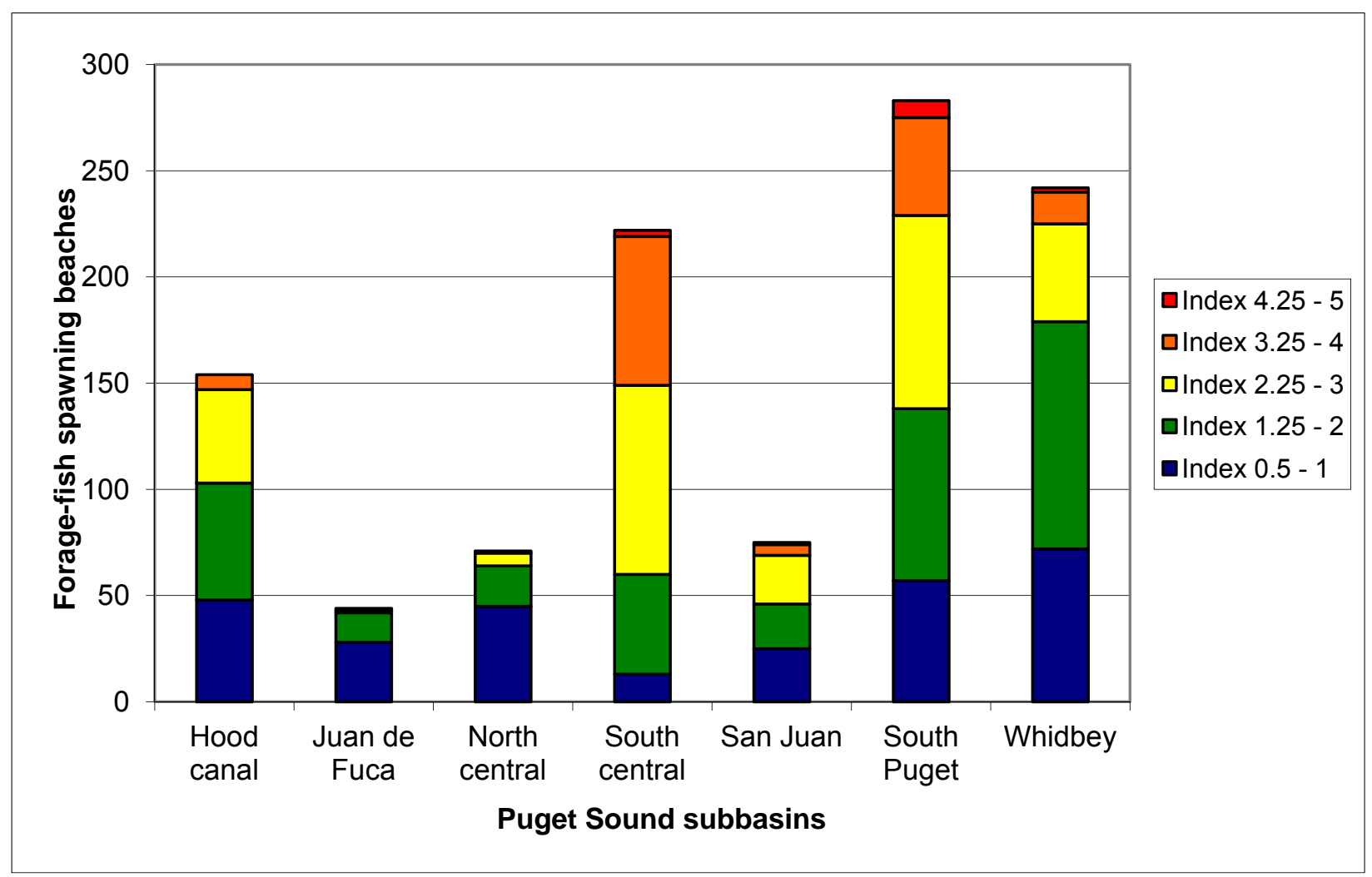

Figure 14. Beach Armoring Index scores at forage-fish spawning beaches by Puget Sound subbasin in the Puget Sound Ecosystem Portfolio Model-year 2000 baseline data. Overall, most forage-fish spawning beaches had moderate to low Beach Armoring Index scores $(0.5$ to 3). Only 159 beaches out of 1,091 had scores of 3.25 to 5 for the year 2000 baseline dataset. Most of these beaches were in the South Puget Sound Subbasin (73 beaches). 


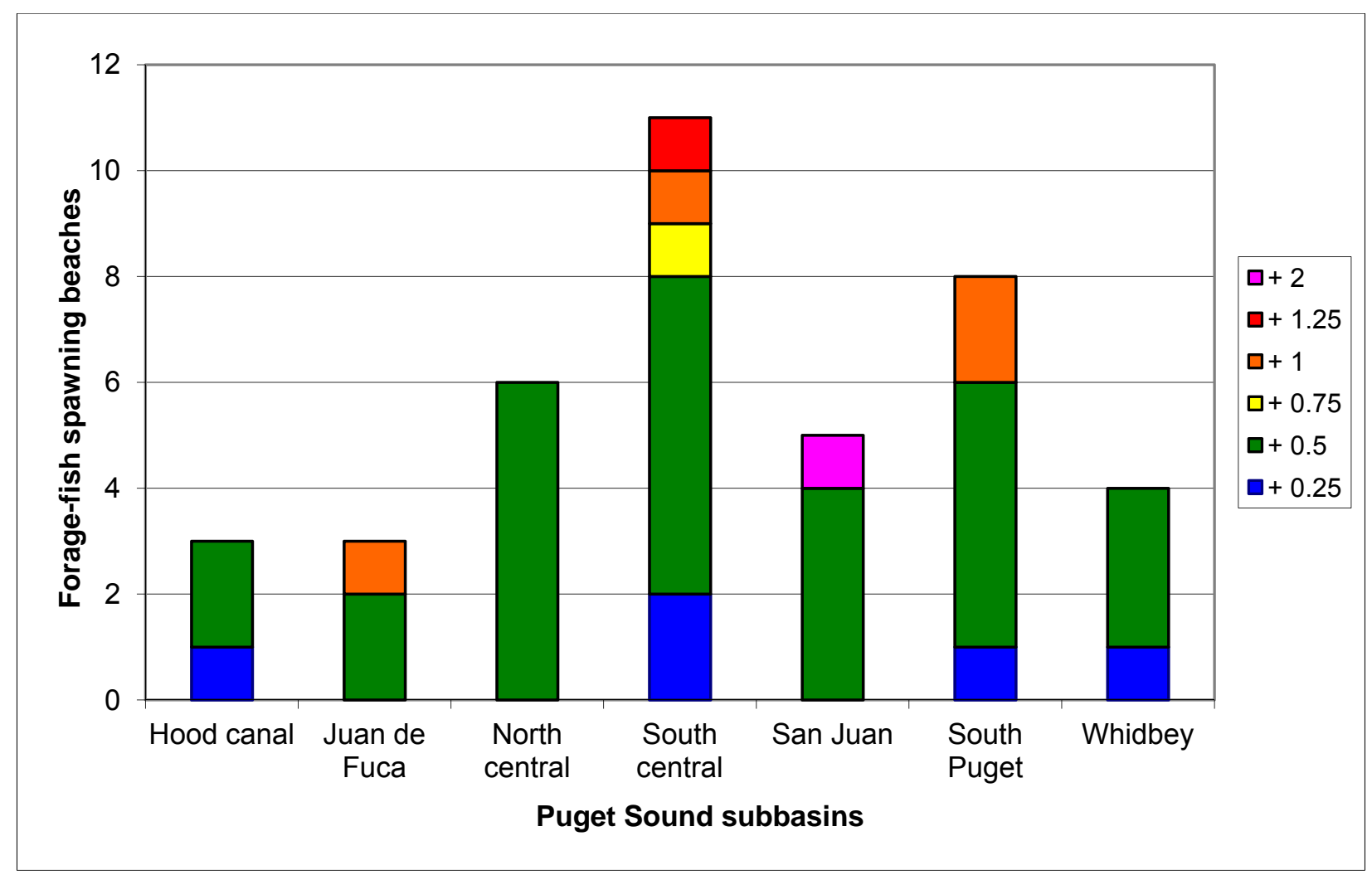

Figure 15. Change in Beach Armoring Index scores at forage-fish spawning beaches by Puget Sound subbasin from 2000 to 2060 under the Unconstrained Growth scenario in the Puget Sound Ecosystem Portfolio Model. Under the Unconstrained Growth scenario, the South Central Subbasin would experience the greatest increase in Beach Armoring Index scores by 2060 , with 11 beaches changing, followed by the South Puget Subbasin, with 8 beaches changing.

Recreational Shellfish Beaches-Recreational Shellfish Harvests and Surrounding Water Quality

Water-quality stations were established at numerous recreational beaches in recent years, which enabled DOH to classify 288 beaches in Washington State in 2009. Over half of these beaches were classified as Approved (http://www.doh.wa.gov/ehp/sf/Pubs/ai-map.pdf, accessed September 12, 2011). There are about 160 additional recreational shellfish beaches in Washington that have not yet been classified due to lack of water-quality data.

Recreational shellfish beaches are classified based on annual harvest data collected by the WDFW. The annual harvest data includes "mean harvest days," which represent the average annual harvest estimations from 2006 to 2008. Harvest data are collected according to the Rafeedie Decision of 1994, a Federal mandate that gives equal shares of shellfishing rights to Native American tribes and the State. Counts are estimates from aerial and on-the-ground surveys conducted during low tides and known popular dates for recreational harvesting. Sampling effort remains relatively constant among years, but is only a sample of each year's actual recreational use of shellfishing beaches. This dataset is therefore critical in determining the relative popularity of beaches for shellfish harvesting. 
Our analysis estimated fecal coliform counts at stations that are within $500 \mathrm{~m}$ of recreational beaches. Recreational beaches are regulated based on water-quality data collected on site. However, in 2000, few stations existed at these beaches. We modeled water-quality data only for nearby stations with existing data for the years 2000 through 2002 (the time period of the 2001 NLCD land-cover data). This analysis provides a rough estimate of potential changes to water quality surrounding recreational shellfish beaches. As more current land-cover data becomes available, we plan to model fecal coliform at recreational shellfish beaches on the basis of associations between land cover and current fecal coliform water quality data collected at these sites.

\section{Recreational Beach Quality -An Intersection of Beach Armoring Index Scores and Recreational Visits at State Beaches, Classified by Access Type}

Variation in beach visitation is often characterized by three main categories describing a recreational site-(1) the site's amenities and characteristics, (2) the environmental condition, and (3) the demand and access (Termansen and others, 2004). Changes to any of these categories can result in a change in visitation and, therefore, a change in the supply of that ecosystem service. In Puget Sound, preferences for nearshore and coastal recreation are likely for sites that are unmodified, in part due to the variety of recreational activities available and their reliance on natural habitats (Leschine and Petersen, 2007). The alteration of natural geomorphic processes could have an effect on the physical and biological characteristics of the Puget Sound coastline. This could reduce recreational visits or the value of an individual visit by changing beach characteristics or by altering habitat quality (Pethick, 2001; Brown and Mclachlan, 2002). Thus, the pattern of future land use could negatively alter the physical shoreform, which would affect coastline features of both human and ecological value.

A comparison of areas where the Beach Armoring Index intersects with areas of high recreational visitation points to areas that may have the largest net changes of recreational ecosystem services. Armoring could alter the coastal environment by disrupting the natural sediment supply necessary for maintaining beaches or for building or supporting shellfish and forage-fish habitat. Although the effects of beach armoring may be present across Puget Sound, in a recreational context, the impacts to State parks may be strongest and most visible at areas that receive many visitors. Values for the Beach Armoring Index range from 0 to 5; however, a value of 3 was the largest index value at a park. The area around Port Townsend (inset, fig. 17) is one such area that has high park visitation (Fort Worden, Fort Flagler, Fort Ebey, and Fort Casey State Parks) and where the parks had a higher than average armoring index value (Port Townsend area $=67,127$ mean park visits and 1.64 armoring index, overall average $=35,753$ mean park visits and 1.22 armoring index). The Beach Armoring Index shows greater spatial than temporal variation among sites and years. As discussed earlier, this is partly due to the input lnad-use/land-cover (LULC) scenarios that did not predict large amounts of shoreline armoring in any scenario. Another reason is the absence of a climate change impact. In future work, LULC scenarios should incorporate sea-level rise to capture the effect of people increasing armoring to counteract increased erosion and storm surge from climate change. 


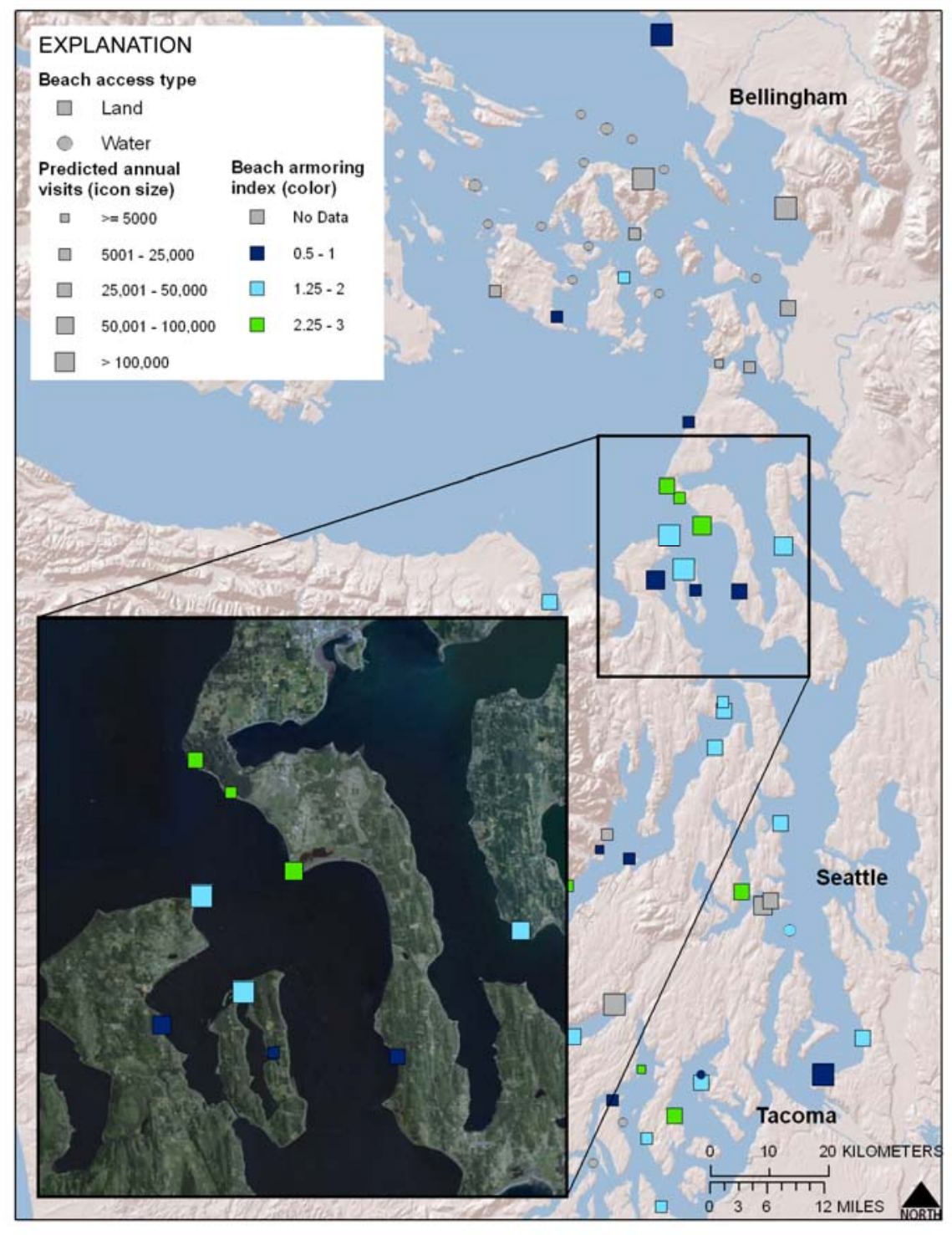

Figure 16. An intersection of Beach Armoring Index scores in the Puget Sound Ecosystem Portfolio Model and recreational visits at Washington State beaches, classified by access type. The area around Port Townsend (inset) is one area that has high park visitation (Fort Worden, Fort Flagler, Fort Ebey, and Fort Casey State Parks) and where the parks had a higher than average armoring index value (Port Townsend area $=67,127$ mean park visits and 1.64 armoring index, overall average $=35,753$ mean park visits and 1.22 armoring index).

\section{Conclusion}

The Puget Sound region continues to experience rapid development and growth in population, which is expected to reach 5.4 million residents by 2025 (Puget Sound Partnership, 2011). This future growth can affect nearshore ecosystem services by increasing water pollution and nutrient loading and by modifying coastal habitats. How land-use decisions are made to accommodate this growth will influence whether Puget Sound environments are further degraded, maintained, or successfully restored. To plan 
for ensuring their long-term sustainability of ecosystem services, resource managers need tools to identify where and why potential impacts to these services may occur.

The PSEPM uses scenarios to evaluate where, when, and to what extent future population growth, urban development, and shoreline development may alter the nearshore environment in the next 50 years. PSEPM model results will improve understanding of potential changes in nearshore ecosystem services by (1) highlighting resource-rich areas that may potentially be affected by multiple stressors, (2) helping to prioritize sites for further study and higher level conservation and restoration planning, and (3) providing planners with the ability to focus on targeted areas to meet regional land-use planning goals.

Coastal planners are also struggling to find ways to prepare for the potential impacts of future climate change, while dealing with immediate management pressures. The distribution and extent of climate-change impacts are highly uncertain and will occur over long time horizons, a situation which complicates decisions on how to respond to future risks (Tompkins and others, 2008). The PSEPM lays the foundation for future work on integrated climate change and the development of land-use-change scenarios to better evaluate potential threats to coastal resources. These scenarios will have the potential to form the basis for integrated assessments and long-term policies that consider human adaptation strategies in response to climate and land-use changes. (Bierwagen and others, 2010).

\section{References Cited}

Alberti, M, 2009, Puget sound future scenarios: Seattle, Wash., University of Washington Urban Ecology Research Lab, 66 p.

Alberti, M., and Bidwell, M., 2005, Assessing the impacts of urbanization on shellfish growing areas in Puget Sound: Seattle, Wash., University of Washington Urban Ecology Research Lab, 79 p.

Anchor QEA, LLC., 2009, Final geospatial methodology used in the PSNERP comprehensive change analysis of Puget Sound, Puget Sound Nearshore Ecosystem Restoration Project: Seattle, Wash., Anchor QEA, LLC, 122 p.

Balmford, A., Beresford, J., Green, J., Naidoo, R., Walpole, M., and Manica, A., 2009, A global perspective on trends in nature-based tourism: Public Library of Science Biology, v. 7, no. 6, e1000144, doi:10.1371/journal.pbio.1000144.

Bateman, I.J., Lovett, A.A., and Brainard, J.S., 1999, Developing a methodology for benefit transfers using geographical information systems-Modelling demand for woodland recreation: Regional Studies, v. 33, p. 191-205.

Bierwagen, B.G., Theobald, D.M., Pyke, C.R., Choate, A., Groth, P., Thomas, J.V., and Morefield, P., 2010, National housing and impervious surface scenarios for integrated climate impact assessments: Proceedings of the National Academy of Science, v. 107, p. 20887-20892.

Booysen, F., 2002, An overview and evaluation of composite indices of development: Social Indicators Research, v. 59, p. 115-151.

Bolte, J., and Vache, K., 2010, Envisioning Puget Sound alternative futures-PSNERP Final Report: Corvallis, Oreg., Oregon State University, 50 p. 
Borde, A., Judd, C., Sather, N., and Thom, R., 2009, East Kitsap County nearshore habitat assessment and restoration prioritization framework: Sequim, Wash., Battelle Pacific Northwest Division, Part of Battele Memorial Institute, Pacific Northwest Division, Richland, Wash., 48 p.

Borja, A., and Dauer, D.M., 2008, Assessing the environmental quality status in estuarine and coastal systems - Comparing methodologies and indices: Ecological Indicators, v. 8, p. 331-337.

Brainard, J., Bateman, I., and Lovett, A., 2001, Modelling demand for recreation in English woodlands: Forestry, v. 74, p. 423-438.

Brennan, J., Culverwell, H., Gregg, R., and Granger, P., 2009, Protection of marine riparian functions in Puget Sound, Washington: Seattle, Wash., Washington Sea Grant, $145 \mathrm{p}$.

Brown, A.C., and McLachlan, A., 2002, Sandy shore ecosystems and the threats facing them- some predictions for the year 2025: Environmental Conservation, v. 29, p. $62-77$.

Burnham, K.P., and Anderson, D.R., 1998, Model selection and multimodel inferenceA practical information-theoretic approach, 2nd ed.: New York, N.Y., SpringerVerlag.

Chan K.M.A., Shaw, M.R., Cameron, D.R., Underwood, E.C., and Daily, G.C., 2006, Conservation planning for ecosystem services: Public Library of Science Biology, v. 4, no. 11, e379, doi:10.1371/journal.pbio.0040379.

Chew K., and Toba, D., 2005, Pacific Coast Shellfish Growers Association shellfish production on the West Coast: Seattle, Wash., Western Regional Aquaculture Center., 1 p., accessed September 26, 2011, at http://www.pcsga.org/pub/uploads/production.pdf.

Clawson M., 1959, Methods of measuring the demand and value of outdoor recreation: Washington, D.C., Resources for the Future, Reprint 10, 36 p.

Coastal Engineering Research Center, 1984, Shore Protection Manual: Washington, D.C., Army Corps of Engineers, 652 p., accessed September 26, 2011, at http://www.archive.org/details/shoreprotectionm01unit.

Coombes, E.G., Jones, A.P., Bateman, I.J. Tratalos, J.A., Gill, J.A., Showler, S.A., Watkinson, A.R., and Sutherland, W.J., 2009, Spatial and temporal modeling of beach use-a case study of East Anglia, UK: Coastal Management, v. 37, p. 94115.

Dethier, M., 2006, Native shellfish in nearshore ecosystems of Puget Sound: Seattle, Wash., Seattle District, U.S. Army Corps of Engineers, 26 p., accessed September 26, 2011, at http://www.pugetsoundnearshore.org/technical_papers/shellfish.pdf.

Englin, J., and Shonkwiler, J.S., 1995, Estimating social welfare using count data models - an application under conditions of endogenous stratification and truncation: Review of Economics and Statistics v. 77, p. 104-112.

Finlayson, D.P., 2006, The geomorphology of Puget Sound Beaches: Seattle, Wash., University of Washington, Ph.D. dissertation, $216 \mathrm{p}$. 
Food and Drug Administration, 2009, National Shellfish Sanitation Program 2009 section II chapter VI shellfish aquaculture national shellfish sanitation program guide for the control of molluscan shellfish, accessed September 27, 2011, at http://www.fda.gov/Food/FoodSafety/Product-

SpecificInformation/Seafood/FederalStatePrograms/NationalShellfishSanitationP rogram/ucm047080.htm.

Glasoe, S., and Christy, A., 2004, Literature review and analysis - coastal urbanization and microbial contamination of shellfish growing areas: Olympia, Wash., Puget Sound Action Team, 29 p., accessed September 26, 2011, at http://www.psparchives.com/publications/our_work/waste/shellfish/sf_lit_review0 604.pdf.

Goldberg, E., 2002, Aggregated environmental indices - Review of aggregation methodologies in use: Paris, Working Group on Environmental Information and Outlooks Organization for Economic Cooperation and Development, 43 p., accessed September 26, 2011, at http://www.oecd.org/officialdocuments/publicdisplaydocumentpdf/? cote $=E N V / E P$ OC/SE\%282001\%292/FINAL\&docLanguage $=$ En .

Gossling, S., 1999, Ecotourism-A means to safeguard biodiversity and ecosystem functions?: Ecological Economics, v. 29, no. 2, p. 303-320.

Greiner, C.M., 2010, Principles for strategic conservation and restoration, Puget Sound Nearshore Ecosystem Restoration Project report no. 2010-01: Olympia, Wash., Washington Department of Fish and Wildlife, and Seattle, Wash., Army Corps of Engineers, 62 p., accessed September 26, 2011, at http://www.pugetsoundnearshore.org/technical_papers/conservation_and_restora tion principles.pdf.

Guerry, A.D., Plummer, M.L., Ruckelshaus, M., Harvey, C.J., 2011, Ecosystem service assessments for marine conservation, in Kareiva, P., Tallis, H., Ricketts, T.H., Daily, G.C., and Polasky, S., eds., Natural Capital-The theory \& practice of ecosystem service valuation in conservation: Oxford, Oxford University Press, $432 \mathrm{p}$.

Hilbe, J.M., 2008, Negative binomial regression: Cambridge, Cambridge University Press, $572 \mathrm{p}$.

Johannessen, J., and MacLennan, A., 2007, Beaches and bluffs of Puget Sound: Seattle, Wash., Seattle District, U.S. Army Corps of Engineers, 34 p. accessed September 26, 2011, at http://www.pugetsoundnearshore.org/technical_papers/beaches_bluffs.pdf.

Johannessen, J., MacLennan, A., and McBride, A. 2005, Inventory and assessment of current and historic beach feeding sources/erosion and accretion areas for the marine shorelines of Water Resources Inventory Areas 8 \& 9: Seattle, Wash., Coastal Geologic Services, Inc., accessed September 26, 2011, at http://green.kingcounty.gov/marine/reports/marine-shoreline.aspx.

Knetsch, J.L., 1963, Outdoor recreation demands and benefits: Land Economics., v. 39, p. 387-96. 
Labiosa, W.B., Bernknopf, R., Hearn, P., Hogan, D., Strong, D., Pearlstine, L., Mathie, A.M., Wein, A.M., Gillen, K., and Wachter, S., 2009, The South Florida Ecosystem Portfolio Model; a map-based multicriteria ecological, economic, and community land-use planning tool: U.S. Geological Survey Scientific Investigations Report 2009-5181, 41 p., accessed September 26, 2011, at http://pubs.usgs.gov/sir/2009/5181/.

Leschine, T.M., and Petersen, A.W., 2007, Valuing Puget Sound's valued ecosystem components: Seattle, Wa, Seattle District, U.S. Army Corps of Engineers, 31 p., accessed September 26, 2011, at http://www.pugetsoundnearshore.org/technical_papers/social_values.pdf.

MacLennan, A., Johannessen, J., and Williams, S., 2010, Bainbridge Island current and historic coastal geomorphic/feeder bluff mapping: Bellingham, Wash., Coastal Geologic Services, Inc., 53 p., accessed September 26, 2011, at http://www.ci.bainbridgeisl.wa.us/documents/pln/shoreline/smpupdate/references/driftcell_1.pdf.

Millennium Ecosystem Assessment, 2005, Ecosystems and human well-beingSynthesis: Washington, D.C., Island Press, 155 p., accessed September 26, 2011, at http://www.millenniumassessment.org/documents/document.356.aspx.pdf.

Mumford, T.F., 2007, Kelp and eelgrass in Puget Sound: Seattle, Wash., Seattle District, U.S. Army Corps of Engineers, 34 p., accessed September 27, 2011, at http://www.pugetsoundnearshore.org/technical_papers/kelp.pdf.

National Research Council, 1999, From monsoons to microbes: understanding the ocean's role in human health: Washington, D.C., Committee on the Ocean's Role in Human Health, National Research Council, National Academy Press, 166 p., accessed Sepember 27, 2011, at http://www.nap.edu/openbook.php?isbn=0309065690.

Parsons, G.R., 2003, A primer for nonmarket valuation: BEpress, p. 269-329, accessed September 27, 2011 at http://works.bepress.com/george_parsons/18.

Penttila, D., 2007, Marine forage fishes in Puget Sound: Seattle, Wash., Seattle District, U.S. Army Corps of Engineers, 30 p., accessed September 27, 2011, at http://www.pugetsoundnearshore.org/technical_papers/marine_fish.pdf.

Peterson, G.D., Cumming, G.S., and Carpenter, S.R., 2003, Scenario planning-A tool for conservation in an uncertain world: Conservation Biology, v. 17, p. 358-366.

Pethick, J., 2001, Coastal management and sea-level rise: CATENA v. 42, no. 2, p. 307322.

Puget Sound Action Team, 2000, Puget Sound water quality management plan: Olympia, Wash., Puget Sound Action Team, 153 p., accessed September 27, 2011, at http://www.psparchives.com/publications/puget_sound/manplan00/MGMTPLAN. pdf.

Puget Sound Action Team, 2002, Puget Sound's health 2002: Olympia, Wash., Puget Sound Action Team, 16 p., accessed September 27, 2011, at http://www.psparchives.com/publications/puget_sound/pshealth2002/pshealth_20 02.pdf. 
Puget Sound Action Team, 2007, 2007 Puget Sound update, ninth report of the Puget Sound Assessment and Monitoring Program, chapter 5, nutrients and pathogens: Olympia, Wash., Puget Sound Action Team, 38 p., accessed September 27, 2011, at http://www.psparchives.com/publications/puget_sound/update/07update/sections/0 7 update-nutrients-pathogens.pdf.

Puget Sound Partnership, 2011, Puget Sound Partnership Web site: accessed August 18, 2011, at http://www.psparchives.com/puget_sound.htm.

Rempel, R., 2010, Patch Analyst 4: Thunder Bay, Ontario, Center for Northern Forest Ecosystem Research, Lakehead University Campus, accessed September 27, 2011, at http://flash.lakeheadu.ca/ rrempel/patch/.

Rooney, R.C., and Bayley, S.E., 2010, Quantifying a stress gradient- An objective approach to variable selection, standardization, and weighting in ecosystem assessment: Ecological Indicators, v. 10, p. 1174-1183.

Schwartz, M.L., Wallace, R.S., and Jacobsen, E.E., 1989, Net shore-drift in Puget Sound: Washington Division of Geology and Earth Resources Bulletin p. 1137-1145.

StataCorp, 2009, Stata Statistical software, release 11: College Station, Texas, StataCorp LP.

Stinchfield, H.M., Koontz, L., and Sexton, N.R., 2008, Social and economic considerations for coastal and watershed restoration in the Puget Sound, Washington-A literature review: U.S. Geological Survey Open-File Report 2009-1079, 78 p., accessed September 27, 2011, at http://pubs.usgs.gov/of/2009/1079/.

Termansen, M., McClean, C.J., and Skov-Petersen, H., 2004, Recreational site choice modeling using high-resolution spatial data: Environment and Planning A, v. 36, p. 1085-1099.

Thom, R.M., Shreffler, D.K., and Macdonald, K., 1994, Shoreline armoring effects on coastal ecology and biological resources in Puget Sound, Washington, Coastal Erosion Management Studies, v. 7: Olympia, Wash., Shoreland and Coastal Zone Management Program, Washington Department of Ecology, 95 p.

Tompkins, E.L., Few, R., and Brown, K., 2008, Scenario-based stakeholder engagement-Incorporating stakeholders preferences into coastal planning for climate change: Journal of Environmental Management, v. 88, p. 1580-1592.

Wallace, R.S., 1988, Quantification of net shore-drift in Puget Sound and the Strait of Juan de Fuca, Washington: Journal of Coastal Research, v. 4, p. 395-403.

Washington State Department of Health, 2004, 2003 Annual inventory-commercial and recreational shellfish areas of Washington State: Olympia, Wash., Office of Food Safety and Shellfish Programs, Washington Department of Health, 23 p.

Washington State Office of Financial Management, 2002, 2002 Population trends for Washington State: Olympia, Wa., Washington Office of Financial Management. $66 \mathrm{p}$.

Weisberg, S.B., Thompson, B., Ranasinghe, J.A., Montagne, D.A., Cadien, D.B., Dauer, D.M., Diener, D., Oliver, J., Reish, D., Velarde, R., and Word, J., 2008, The level of agreement among experts applying best professional judgment to assess the condition of benthic infaunal communities: Ecological Indicators, v. 8, p. 389394. 